\title{
Pensions, Ageing and Social Security Research: Literature Review and Global Trends
}

\author{
María del Carmen Valls Martínez ${ }^{1, * \mathbb{D}}$, José Manuel Santos-Jaén ${ }^{2} \mathbb{D}$, Fahim-ul Amin ${ }^{3} \mathbb{D}$ \\ and Pedro Antonio Martín-Cervantes ${ }^{1}$ (i)
}

1 Mediterranean Research Center on Economics and Sustainable Development (CIMEDES), Department of Economics and Business, University of Almería, 04120 Almería, Spain; pmc552@ual.es

2 Department of Financial Economics and Accounting, University of Murcia, 30100 Murcia, Spain; jmsj1@um.es

3 School of Economics and Management, Chang'an University, Xi'an 710064, China; fahimulamin@gmail.com

* Correspondence: mcvalls@ual.es

check for updates

Citation: Valls Martínez, M.d.C.;

Santos-Jaén, J.M.; Amin, F.-u.;

Martín-Cervantes, P.A. Pensions, Ageing and Social Security Research: Literature Review and Global Trends. Mathematics 2021, 9, 3258

https://doi.org/10.3390/math9243258

Academic Editor: Antonella Basso

Received: 17 November 2021

Accepted: 14 December 2021

Published: 15 December 2021

Publisher's Note: MDPI stays neutral with regard to jurisdictional claims in published maps and institutional affiliations.

Copyright: (c) 2021 by the authors. Licensee MDPI, Basel, Switzerland. This article is an open access article distributed under the terms and conditions of the Creative Commons Attribution (CC BY) license (https:// creativecommons.org/licenses/by/ $4.0 /)$.

\begin{abstract}
Pension systems are one of the fundamental pillars of the welfare state. The ageing of the population caused by longer life expectancy and low birth rates has led to a crisis in the public pension system in developed countries. Changes for the system's sustainability are necessary, and the scientific literature on the subject is abundant, especially in recent years. This article aims to carry out a bibliometric analysis of the research carried out to date, highlighting, in turn, future lines of research. The study was carried out on a total of 1287 articles published from 1936 to 2021 and found in the Scopus database. The SciMAT, VOSviewer, and Datawrapper tools were used to analyse the most important articles, authors, countries, and institutions by volume of production and citations, as well as the relationships between them. Likewise, the most important keywords and their evolution over time were highlighted, obtaining the main focus of the research. In addition to the general analysis, a specific study was carried out in the area of Mathematics. The results show that the leading countries are the United Kingdom, the USA, and the Netherlands. On the other hand, the lead subject area in which these articles have been published is Economics, Econometrics, and Finance. The research trends are sustainability, pension reform related to ageing, and pension insurance.
\end{abstract}

Keywords: pensions; ageing; longevity; social security; bibliometric; review

\section{Introduction}

In recent years, researchers, public institutions, and individuals have become concerned about the sustainability of current pension systems [1], representing the most severe and enduring challenge for developed and developing welfare states [2]. This has been due to the increase in life expectancy coupled with the sharp reduction in the birth rate [3], which has led to the search for a new system that will guarantee their viability in the future [4]. Although many reforms have been implemented in recent years, they are considered insufficient to ensure the long-term sustainability of pensions $[1,5]$.

The search for this necessary sustainability has given rise to incipient literature in the field of pensions, over the last decades, addressing aspects, such as the study of the different pension typologies [6,7]; the interaction between public and private pension systems [8]; the possible existence of a gender gap [9]; the reduction of pensions or the increase in workers' contributions [10]; the analysis of new capitalisation systems [11,12]; or the study of demographic aspects, including age [13-15], educational level [16], place of residence [17], or belonging to certain groups [18].

However, the main challenge underlying the research is to solve the problem of the stability of the public social security system. Improvements in health care and quality of life have led to an ageing population, i.e., a lengthening of the retirement period. The higher cost of the pension system is jeopardising its stability, even in the short term. There are only two solutions if the current philosophy of the system is to be maintained: to 
increase revenue through higher contributions or reduce expenditure. The former can only be achieved by increasing the number of contributors (which, with unemployment levels and low birth rates, does not seem to be the solution) or the contribution paid by workers and companies. The latter implies a reduction in the amount of pensions or a delay in the retirement age. The challenge for researchers is to propose models that anticipate the results, using statistics, econometrics, and actuarial methodology.

This study has carried out a systematic review of the existing literature on pensions, intending to obtain the most critical and up-to-date knowledge on a topic of current concern, such as the sustainability of pensions in the future. To this end, bibliometric techniques have been applied to review the literature and find out which are the most influential authors, works, journals, and institutions, as well as the current trends in this area of research $[19,20]$.

Since 1936, when the first article on pensions was published, the scientific community's interest has been growing and has addressed a variety of topics. Initially, research focused on issues related to life expectancy and the ageing of the population. Over the years, researchers have managed the need to reform the various pension systems to ensure their long-term survival.

The present bibliometric analysis will examine the scientific output and represent the existing knowledge on pension research [21], which is possible thanks to the use of bibliometric indicators, as they provide valuable information on scientific production in its different expressions [22,23]. This bibliometric analysis will provide the scientific community with very interesting information on the current state of pensions research and help establish future research lines [24].

The purpose of this research is to analyse current trends in pension research. To this end, 1287 articles published in journals indexed in the Scopus database and published from 1936 to 2021 have been analysed using bibliometric techniques. These studies have been published in different areas of knowledge, such as economics, social sciences, business, or mathematics. Although the concern for this research topic has been growing in recent years, we have not found any bibliometric study on this field of research.

For the reason described above, this paper makes significant contributions to the literature on pensions by carrying out an exhaustive analysis of indicators, namely author production, the collaboration between authors, countries, institutions, or citations. Furthermore, this study has been carried out using three complementary tools: DataWrapper, Excel, VOSviewer, and SciMAT, which, together with the data used, offer a current and global view of the research carried out on pensions. Finally, we can state that the study carried out makes an essential contribution to the theoretical field of pension research by helping the scientific community to know what the main research topics are, how the concerns of scientists have changed since the publication of the first articles on the subject and, especially, to find new lines of research.

The rest of the article is structured as follows: Section 2 develops a literature review; Section 3 explains which materials have been used and applied methods to conduct the bibliometric analysis; Section 4 presents the results; Section 5 provides a detailed discussion of the results obtained; and, finally, Section 6 offers the main conclusions reached.

\section{Literature Review}

The social security systems prevailing in Europe, created by Bismarck in Germany and Beveridge in England at the end of the 19th century, are the basis of the current pension systems prevalent in most developed countries. The State guarantees, through the social security system, contributory and non-contributory pensions for retirement [25], disability [26], widowhood [27], and orphanhood [28]. These are distributive pension systems, i.e., where the income generated by current workers pays current pensions. The future pensions of current workers will be paid by those who will be active at the time of their retirement. In short, the pensions of one generation are not paid for by their own contributions but by the next generation $[29,30]$. 
This operating scheme requires an adequate ratio of pensioners to workers. This is precisely where its weaknesses lie, as manifested in recent years by the different governments' problems in guaranteeing payments. The birth rate in developed countries has decreased, while the increase in life expectancy has led to a high number of people of retirement age [31]. In short, the ageing of the population poses a problem for the sustainability of the traditional pension system [32-35], jeopardising its future viability [36,37].

Faced with this situation, some countries, such as the United Kingdom [38,39] and the U.S.A. [40-43], have begun to carry out reforms to reduce the governmental cost of pensions. These reforms can be grouped into two broad categories well differentiated from each other.

The first group of measures does not affect the established pension model. It involves either reducing the amount of pensions to be accrued in the near future or increasing workers' contributions to the system $[10,44,45]$. For this purpose, parametric adjustments are made, such as increasing the number of years considered for calculating the pension amount or a delay in the retirement age. Generally, workers earn lower salaries at the beginning of their working life, and as they have more experience and seniority, their wages increase [46]. Therefore, if the number of years in which the pension is calculated is extended beyond those closest to retirement age, the pension will be reduced, relieving system stress.

On the contrary, the second type of measures involves a change in the distributive system towards a capitalisation system, similar to that carried out with private pension plans, where the contribution that a person makes during her/his working life is the one that will later nourish her/his own retirement pension [47]. This system transfer does not occur all at once, but gradually, several generations are necessary for the transfer to be complete. An intermediate option can also be found, i.e., a hybrid system, in which the State guarantees a minimum pension supplemented by private pension plans [11,12,48-50]. The State will provide tax incentives to encourage the personal investment in private plans during working life.

The literature has established a relationship between private savings for retirement, with factors, such as the educational level [16], area of residence [17,51], or age [13,14,52] of the individual, as well as with specific sectors of society $[53,54]$ (for example, immigrants [18]), and even based on the different economies of nations [55,56].

We must consider that longevity involves significant economic risk. A person can live more than thirty years after retirement [57], which implies monetary needs that can exceed their savings forecasts [5], which requires new pension systems and financial products to cover the needs at this time of life [4]. In this sense, pension insurance and mixed savings-hedging products, such as unit-linked products, are being developed [58].

\section{Materials and Methods}

In bibliometric analysis, two techniques are used to evaluate the scientific activity and impact of research and its sources [59]. These techniques are bibliometric indicators and scientific mapping $[60,61]$. These measures for analysing scientific activity are classified into activity indicators and impact indicators. The former allows us to visualise the actual state of science, providing us with information on the number of publications and their dispersion, the collaboration between authors, or ageing. On the other hand, the latter evaluate highly cited documents and the impact factor of journals, which is currently the best known [62].

With regard to scientific mapping, it enables us to carry out relations between authors, keywords, and journals. Likewise, scientific mapping can be used to identify current trends or emerging topics. It is important to point out that these techniques are not mutually exclusive. When treated together, they allow us to know the existing relationships between disciplines, authors, keywords, and even documents [63].

In order to analyse and visualise the scientific literature, software packages were used. To represent the interactions between authors, countries, and keywords, VOSviewer was 
used [63-65]. On the other hand, SciMat was used to find the substructures that grouped words during a specific period [66]. Similarly, for the choropleth maps, Datawrapper has been used. In addition, Microsoft Excel has been used to produce descriptive figures and tables.

Various aspects of scientific production can be measured by applying mathematical and statistical techniques by carrying out a bibliometric analysis [67-69]. These analyses identify and illustrate crucial elements, such as authors, documents, or countries. These elements allow us to obtain valuable information on the evolution of science in different research fields [66-70].

This research tries to show the evolution experienced in the study carried out on pensions, ageing, and social security. In the same way, as other authors have done before [60,71,72], this bibliometric analysis has been developed following the following scheme of work: firstly, the field of study has been defined; secondly, we have determined the database to provide us with the information necessary to carry out the different analyses.; thirdly, we have adjusted the criteria used in the research, determining aspects, such as the type of documents to be searched, the language, the terms, or even the parts of the documents to be explored; fourthly, we have exported the valid results once we have obtained the database; fifthly, the data were processed with the software mentioned above; and, finally, the results obtained were analysed and discussed. Figure 1 shows a summary of the process followed.

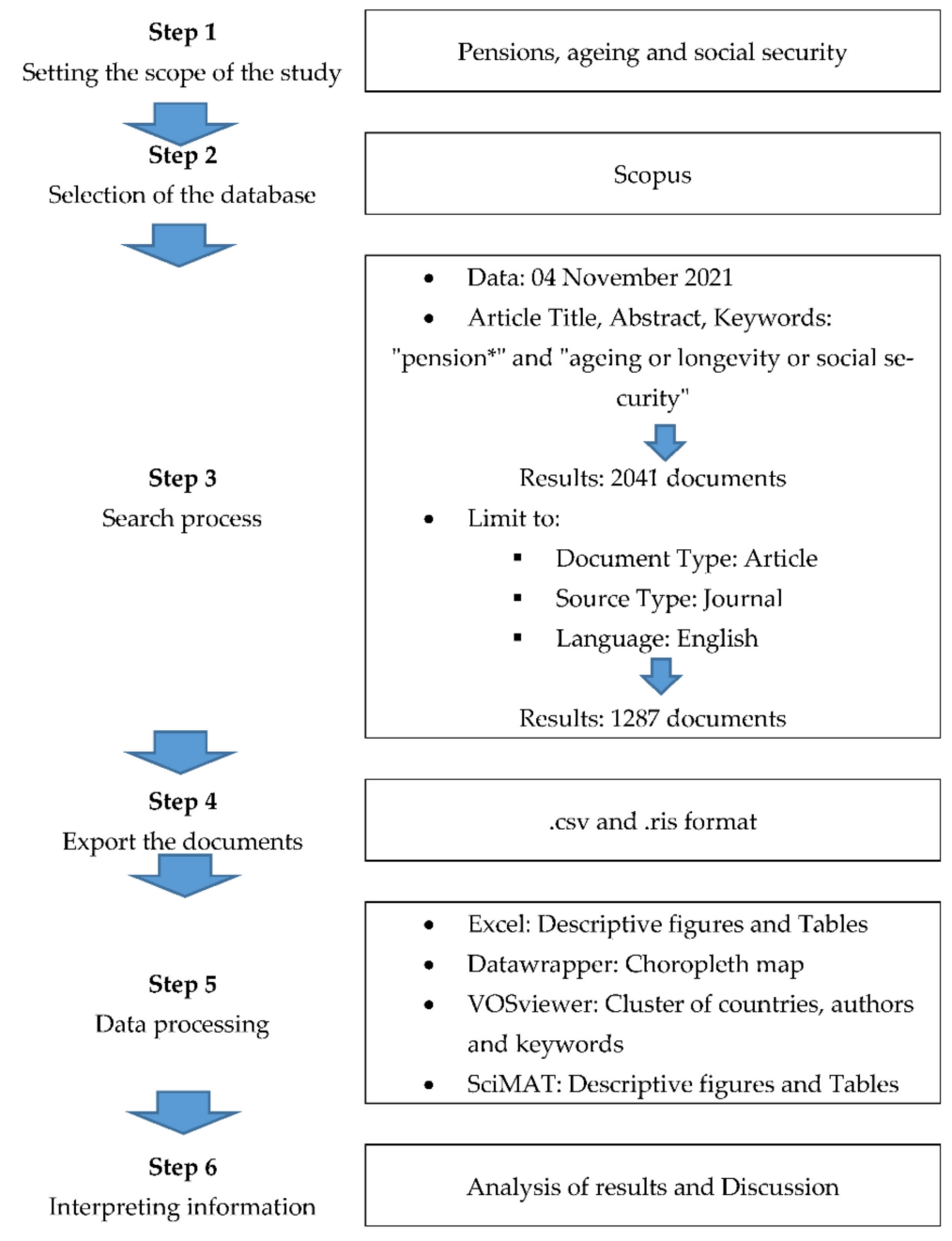

Figure 1. Flowchart methodology.

\subsection{Search Criteria and Database}

Nowadays, we can find several databases (for instance, Scopus, Google Scholar, Web of Science). Each database uses different tools and techniques to analyse the data. When we examine the bibliometric studies carried out previously, we can see that the vast majority 
use of either Web of Science or Scopus [60]. Considering that most of the articles in Web of Science are also present in Scopus, this situation does not occur the other way around. We have decided to use the Scopus database to have a more significant number of sources [73].

To obtain the data, and taking into account the object of our research, the search criteria used in Article Title, Abstract, and Keywords were "pension*" and "ageing or longevity or social security". The search took place on 4 November 2021 and covered the period from 1936 (the year in which the first article on pensions was published) to 2021. Initially, the search gave us an initial result of 2041 documents. However, once all documents that were not English language journal articles were removed, the final result was 1287 documents.

\subsection{Data Extraction}

The results obtained were downloaded in both R.I.S. and CSV formats. In order to carry out the bibliometric analysis, these data were processed with SciMAT (v1.1.04), Microsoft Excel (version 2016), Datawrapper (online version), and VOSviewer (v1.6.16). The data obtained provided information on article names, article authors, keywords used, article titles, and citation information.

\subsection{Data Analysis}

Three tools, VOSviewer, Datawrapper, and SciMAT, have been used to carry out the data analysis. VOSviewer is used to illustrate, visualise, and even explore the scientific maps $[63,66]$. This tool allows knowing networks of authors, countries, and keywords. [73,74]. Datawrapper is a tool that allows the creation of choropleth maps, which enables users to grasp the data easily [75]. SciMAT makes it easy to recognise the associations and interactions between research topics. In addition, emerging research themes can also be discovered [76].

The descriptive analysis of the data was carried out using Excel, although VOSviewer was also used to obtain the distribution of the research output and analyse the keywords used. Datawrapper showed the visual representation of scientific production at the global level. Finally, SciMAT allowed recognising current research trends.

The results obtained in this research are of great use to the scientific, public and private institutions, and even to the general public, as the future of the current pension system is currently a major concern.

\section{Results}

In order to carry out the bibliometric analysis, this section has been divided into two subsections: descriptive analysis and content analysis. The descriptive analysis shows the evolution of the papers published in the field under study and the citations received by these papers. It also shows the distribution of articles by journals, institutions, subjects, and countries. Finally, information is provided on the most prolific and influential authors. The content analysis allows us to know the current trends in pension research and the areas that have undergone the most remarkable development [77]. Table 1 shows a summary of the data used in this research.

Table 1. Summary of data on pension research.

\begin{tabular}{cc}
\hline Data & Pension Research \\
\hline Number of articles & 1287 \\
Number of journals & 536 \\
Number of authors & 2035 \\
Number of countries & 112 \\
Number of citations & 10663 \\
Average citations/article & 8.29 \\
Average citations/authors & 5.24 \\
\hline
\end{tabular}

Source: own elaboration.

In addition, we have created a third sub-section in which we analyse only the articles published within the thematic area of mathematics. 


\subsection{Descriptive Analysis}

\subsubsection{Evolution of Scientific Production}

As shown in Table 2 and Figure 2, pensions are a topic of interest to researchers.

Table 2. Major characteristics of the scientific production on pension research.

\begin{tabular}{cccccccc}
\hline Year & A & AU & AU/A & C & J & TC & TC/A \\
\hline $1936-1971$ & 12 & 12 & 1.00 & 3 & 11 & 0 & 0.00 \\
$1972-1976$ & 24 & 26 & 1.08 & 7 & 10 & 4 & 0.17 \\
$1977-1981$ & 20 & 16 & 0.80 & 4 & 11 & 125 & 6.25 \\
$1982-1986$ & 28 & 37 & 1.32 & 8 & 22 & 192 & 6.86 \\
$1987-1991$ & 32 & 41 & 1.28 & 11 & 26 & 153 & 4.78 \\
$1992-1996$ & 42 & 64 & 1.52 & 19 & 26 & 489 & 11.64 \\
$1997-2001$ & 117 & 160 & 1.37 & 26 & 68 & 1837 & 15.70 \\
$2002-2006$ & 123 & 195 & 1.59 & 32 & 75 & 2260 & 18.37 \\
$2007-2011$ & 227 & 401 & 1.77 & 59 & 118 & 2353 & 10.37 \\
$2012-2016$ & 283 & 509 & 1.80 & 59 & 183 & 2376 & 8.40 \\
$2017-2021$ & 379 & 847 & 2.23 & 73 & 222 & 874 & 0.23 \\
\hline A: number of articles; & A.U: number of authors; AU/A: number of authors by article; C: number of countries:
\end{tabular}

A: number of articles; A.U.: number of authors; AU/A: number of authors by article; C: number of countries; J: number of journals; T.C.: total citations obtained by the articles; the TC/A: total citations per article. Source: own elaboration.

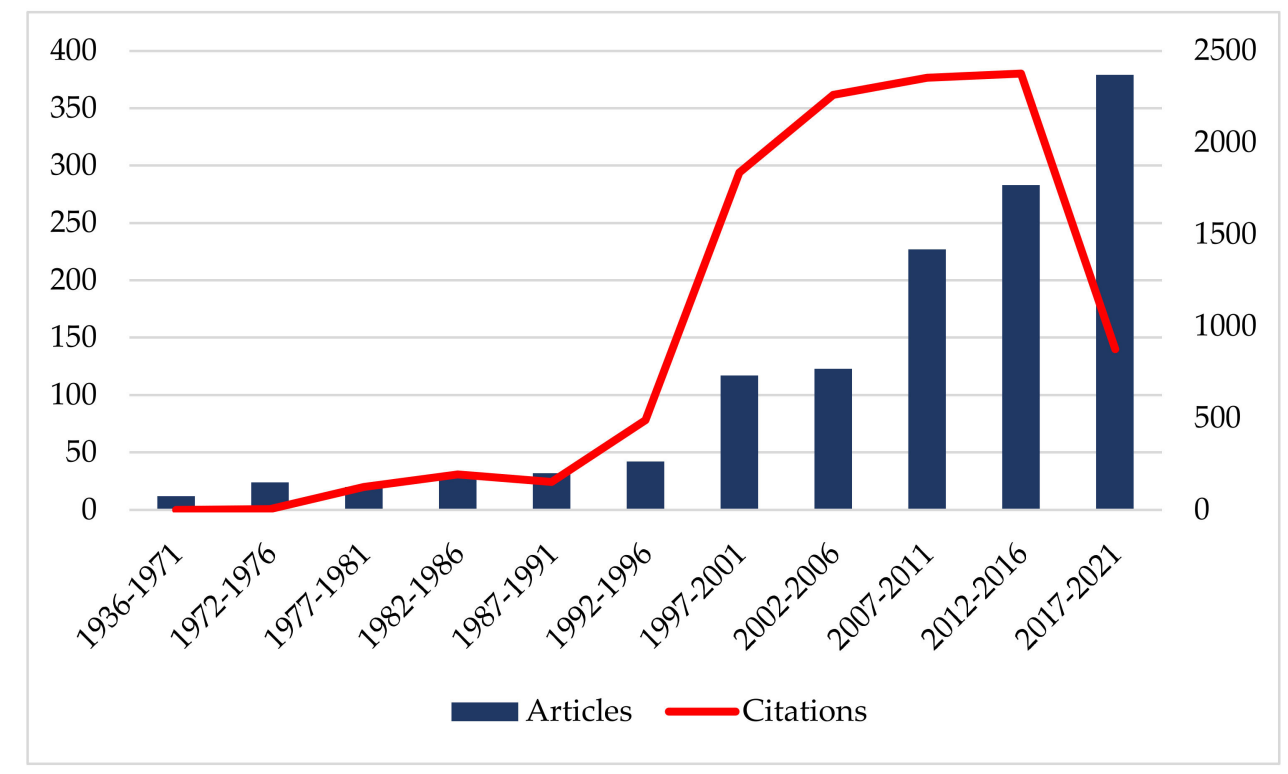

Figure 2. Evolution over time of the published articles in each period on pension research and the total number of citations they have obtained. The left axis represents the number of published articles, and the right axis the number of citations received by the published articles. Source: own elaboration.

Since the first article was published, in 1936 up to the present day, they have experienced a very significant growth. Especially, at the end of the 20th century, there was an increase in interest for researchers. It can also be observed that interest has increased even more in the recent years, as the number of articles published has grown exponentially. It is worth noting that more articles have been published on pensions in the last ten years than in the previous 75 years, which shows the growing interest in this topic today.

Figure 2 also exhibits the significant evolution of the number of citations received by the articles published in each period, demonstrating the interest in the future sustainability of pensions. The decline in the number of citations in the last period should be interpreted with caution, as not enough time has yet passed for these articles to generate citations, especially those published in the previous few years.

Table 2 shows how the number of authors, the number of journals, and the number of interested countries that published articles on pensions grew over the analysed period. The 
number of authors and journals has experienced a similar evolution to that described above for articles. In other words, from 1997 onwards they increased considerably. It is significant to note that authors from 73 countries have worked on the study of pensions in the last five years, which shows the growing and general interest. The number of citations received has also increased in recent years. The number of countries with authors publishing on pension-related topics grew significantly from 2007 onwards. However, due to the more extended exposure period, the articles published between 2002 and 2006 have received the highest number of citations per article.

\subsubsection{Distribution of Scientific Production}

The articles on pensions have been classified into several thematic areas by the database. Figure 3 depicts these subject areas and indicates the percentage of published articles. The results show that the 3 most relevant areas are economics, econometrics and finance (32.77\%), social sciences $(28,45 \%)$ and business, and management and accounting $(12.12 \%)$. These 3 areas account for $73.34 \%$ of the articles published. The remaining areas, including medicine, environmental sciences, and mathematics, account for the remaining $26.66 \%$.

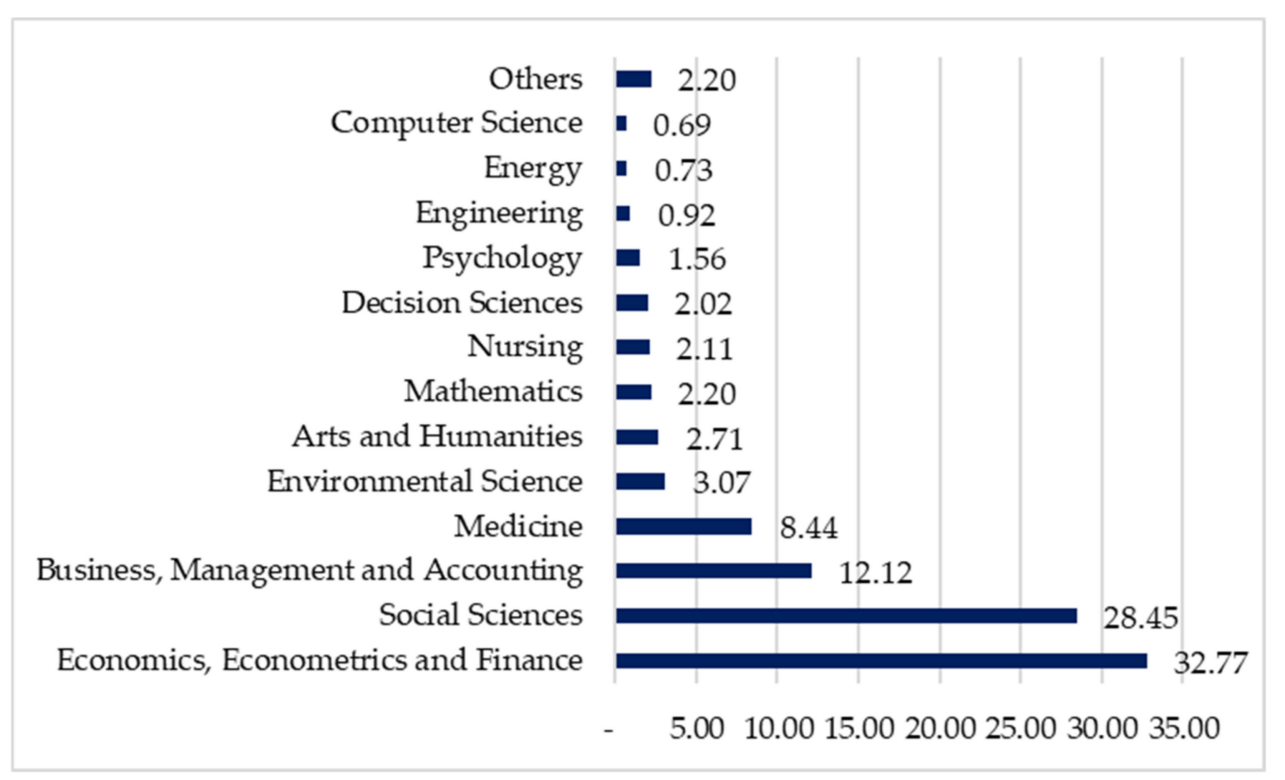

Figure 3. Documents by subject area (percentage) on pension research. Source: own elaboration.

The age-related pension problem of the social security system is an economic problem of financing: the shortage of funds in relation to the pensions to be paid. The solution involves econometric analyses that anticipate the future situation, that foresee possible scenarios based on the current situation. In other words, it is mainly a problem of economics, finance, and econometrics.

Table 3 shows the ten most productive journals in the field of pension-related research. These journals have published 340 articles (26.41\% of the articles published). This figure, together with the large number of journals that have published papers on pensions (536), shows the wide dispersion of work on the subject.

The journal that has issued the most articles is the International Social Security Review, which is specialised in the matter, as its name suggests. Specifically, it has published 122 papers (9.4\% of the total number of articles published) since 1970, the year in which it published its first article on pensions. It can also be seen that this journal has received a total of 1092 citations $(10.24 \%$ of the total number of citations received by articles on pensions). As for the nationality of these journals, it is worth noting that eight are published in Europe and two in the United States. The UK and the Netherlands share four of the European journals. It is also significant that 2 of the 10 journals are in quartile 1 of the 
SCImago Journal Rank (S.J.R.); the rest (except for 1 discontinued journal) are in quartile 2, which indicates a good interest in the subject of pensions in high-impact journals.

Table 3. The top 10 most productive journals on pension research.

\begin{tabular}{|c|c|c|c|c|c|c|c|c|c|}
\hline Journal & A & $\mathrm{C}$ & TC & TC/A & 1st A & Last $\mathrm{A}$ & $\mathrm{TC} / \mathrm{Y}$ & $\operatorname{SJR}(Q)$ & h-Index \\
\hline International Social Security Review & 122 & U.K. & 1092 & 8.95 & 1970 & 2021 & 21.41 & $0.349(\mathrm{Q} 2)$ & 17 \\
\hline $\begin{array}{l}\text { Journal of Pension Economics } \\
\text { and Finance }\end{array}$ & 55 & U.K. & 483 & 8.78 & 2002 & 2021 & 25.42 & $0.501(\mathrm{Q} 2)$ & 12 \\
\hline Social Security Bulletin & 33 & U.S.A. & 116 & 3.52 & 1974 & 2020 & 2.47 & $0.365(\mathrm{Q} 2)$ & 5 \\
\hline Pensions & 24 & U.K. & 50 & 2.08 & 2009 & 2012 & 4.17 & - & 4 \\
\hline Journal of Public Economics & 23 & The Netherlands & 892 & 38.78 & 1978 & 2021 & 20.74 & 3.826(Q1) & 16 \\
\hline Journal of Ageing and Social Policy & 20 & U.S.A. & 186 & 9.3 & 1996 & 2021 & 7.44 & $0.450(\mathrm{Q} 2)$ & 6 \\
\hline Ageing and Society & 18 & U.K. & 207 & 11.5 & 1989 & 2020 & 6.47 & $0.770(\mathrm{Q} 1)$ & 9 \\
\hline Journal of the Economics of Ageing & 16 & The Netherlands & 87 & 5.44 & 2014 & 2021 & 12.43 & $0.529(\mathrm{Q} 2)$ & 6 \\
\hline $\begin{array}{l}\text { Geneva Papers on Risk and } \\
\text { Insurance: Issues and Practice }\end{array}$ & 15 & U.S.A. & 125 & 8.33 & 1999 & 2016 & 5.68 & $0.535(\mathrm{Q} 2)$ & 6 \\
\hline $\begin{array}{l}\text { Insurance: Mathematics } \\
\text { and Economics }\end{array}$ & 14 & The Netherlands & 155 & 11.07 & 2008 & 2021 & 11.92 & 1.139(Q1) & 7 \\
\hline
\end{tabular}

A: number of articles; C: country; T.C.: total citations; TC/A: total citations by article; First A: year corresponding to first published article; Last A: year corresponding to last published article; TC/Y: average number of citations per year since the first published article; S.J.R. (Q): Scimago Journal Rank (Quartile in 2020); and h-index: Hirsch in this topic. Source: own elaboration.

A total of 112 countries have published articles on pensions. These countries are represented in Figure 4. However, as shown in Table 4, half of the articles, 647 out of 1287, have been published in 4 countries. It should be noted that an article can cover more than one country, as authors can co-author it from different institutions.

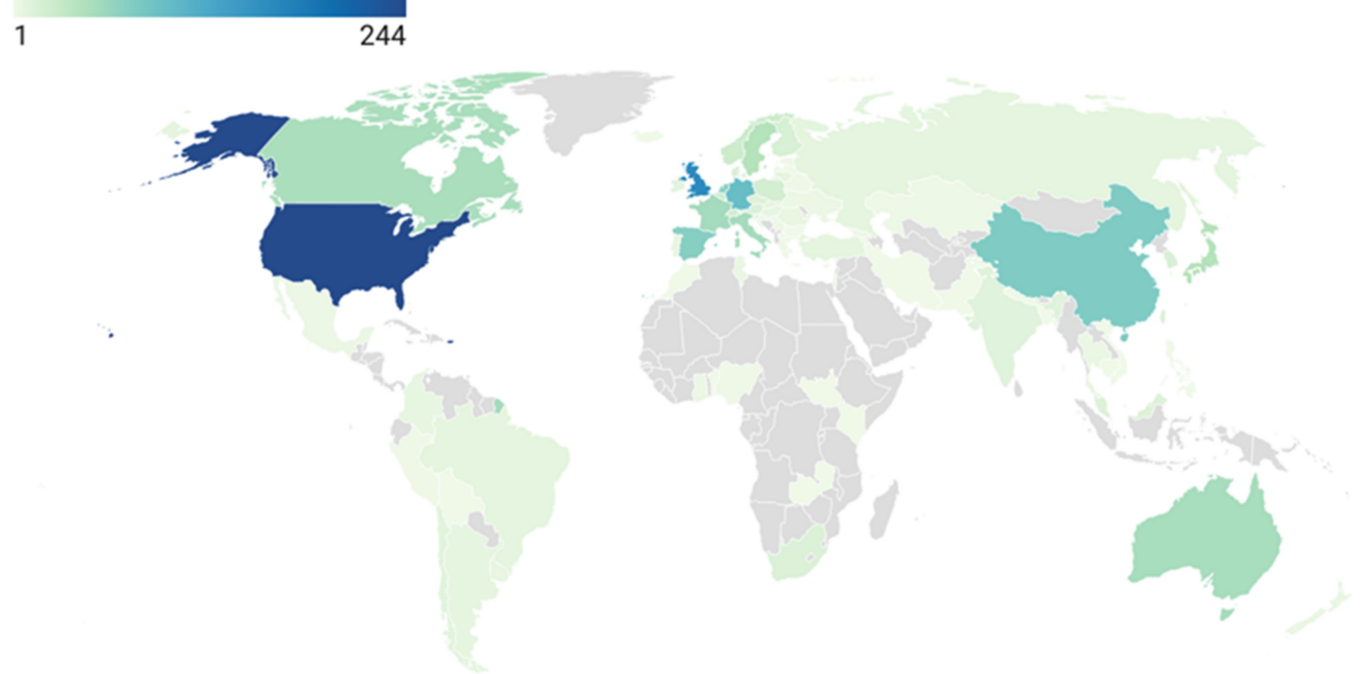

Figure 4. Worldwide publications on pension research. Source: own elaboration.

The most prolific country is the U.S.A., with $18.95 \%$ of publications (244 articles), followed by the U.K. with $12.43 \%$ (160 articles), and Germany with $7.38 \%$ (95 articles). China and Spain are in fourth and fifth place with 76 and 72 articles, respectively. Table 5 also shows how this higher publication of articles by country does not correspond to the position in terms of the citations per article received. Thus, in this case, although the U.S.A. is still first, the second position is occupied by Germany and the third by the U.K., with the Netherlands and Australia also standing out among the top five countries in terms of citations per article. 
Table 4. The top 10 most productive countries on pension research.

\begin{tabular}{cccccccc}
\hline Country & A & TC & TC/A & 1st A & Last A & TC/Y & h-Index \\
\hline U.S.A. & 244 & 3264 & 13.38 & 1972 & 2021 & 66.61 & 29 \\
U.K. & 160 & 1848 & 11.55 & 1976 & 2021 & 41.07 & 22 \\
Germany & 95 & 1263 & 13.29 & 1989 & 2021 & 39.47 & 21 \\
China & 76 & 361 & 4.75 & 2004 & 2021 & 21.24 & 11 \\
Spain & 72 & 495 & 6.88 & 1995 & 2021 & 19.04 & 11 \\
The Netherlands & 69 & 739 & 10.71 & 1990 & 2021 & 23.84 & 14 \\
France & 53 & 436 & 8.23 & 1993 & 2021 & 15.57 & 13 \\
Italy & 52 & 327 & 6.29 & 1995 & 2021 & 12.58 & 10 \\
Australia & 51 & 512 & 10.04 & 1979 & 2021 & 12.19 & 12 \\
Canada & 49 & 448 & 9.14 & 1975 & 2021 & 9.73 & 13
\end{tabular}

A: number of articles; T.C.: total citations; TC/A: total citations by article; First A: year corresponding to first published article; Last A: year corresponding to last published article; TC/Y: average number of citations per year since the first published article; and h-index: Hirsch in this topic. Source: own elaboration.

Table 5. Top 10 most cooperative countries and main collaborators.

\begin{tabular}{ccccc}
\hline Country & A & C & NC & Main Collaborators \\
\hline U.S.A. & 241 & 3264 & 96 & U.K., China, Germany \\
U.K. & 160 & 1848 & 76 & U.S.A., Italy, Australia \\
Germany & 95 & 1263 & 50 & U.S.A., The Netherlands, U.K. \\
The Netherlands & 69 & 739 & 37 & Germany, Italy, U.S.A. \\
France & 53 & 436 & 36 & Belgium, U.K., Canada \\
Belgium & 26 & 254 & 31 & France, U.S.A., Germany \\
China & 76 & 361 & 30 & U.S.A., Canada, U.K. \\
Canada & 49 & 448 & 27 & U.S.A., China, France \\
Italy & 52 & 327 & 26 & U.K., The Netherlands, U.S.A. \\
Australia & 51 & 512 & 22 & U.K., U.S.A., Norway \\
\hline
\end{tabular}

A: number of articles, C: number of citations; and NC: number of collaborations. Source: own elaboration.

Concerning the h-index, the top 3 positions coincide with the most prolific countries; the U.S.A. with 29, the U.K. with 22, and Germany with 21. However, the fourth position goes to the Netherlands with 14 and France and Canada share the fifth position with 13.

Figure 5 depicts networks showing cooperation among the 47 major countries that have published pension research. The colour of each of the spheres corresponds to a grouping of countries, while the size represents the number of articles published per country.

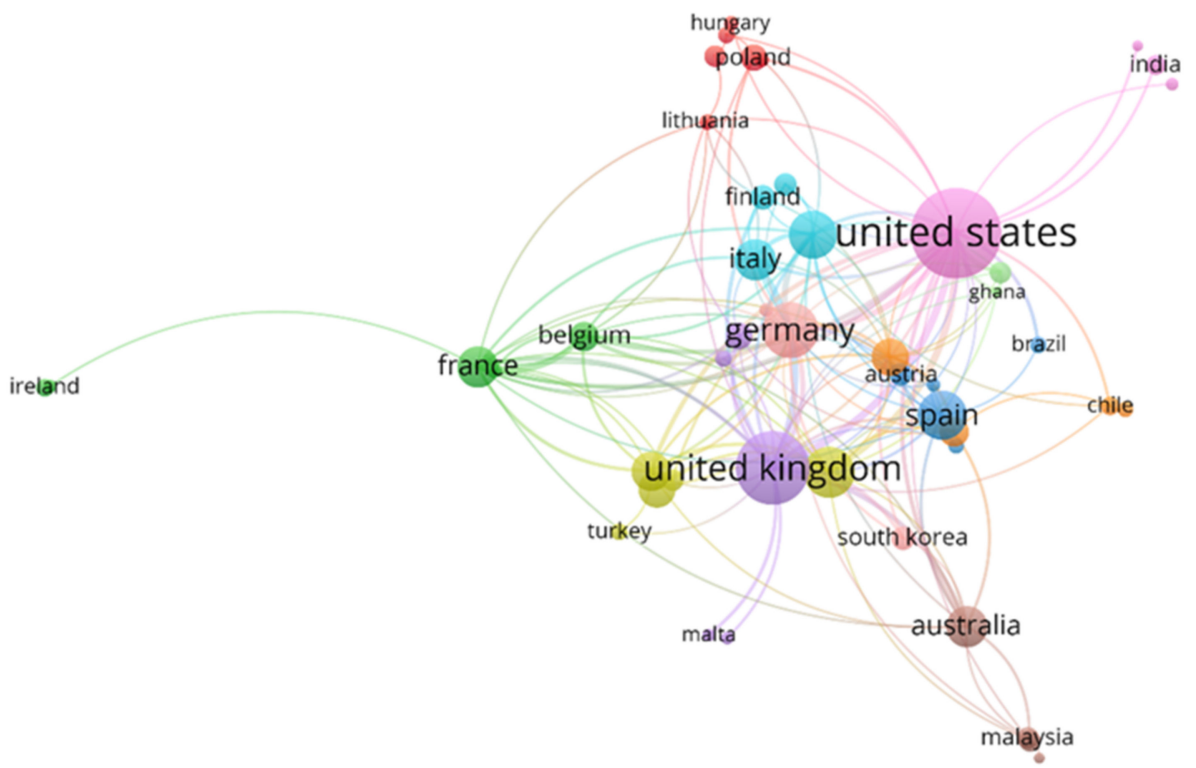

Figure 5. Network of cooperation based on authorship between countries. Source: own elaboration. 
Eleven different groups have been observed. The red group includes the Czech Republic, Hungary, Lithuania, Poland, Slovakia, and Slovenia. The countries associated with the green colour are Belgium, Colombia, France, Ireland, Luxembourg, and Tunisia. The blue cluster, headed by Spain, also includes Brazil, Israel, Portugal, and Austria. The yellow group is led by China, with Canada, Japan, Taiwan, and Turkey as collaborators. The purple group, led by the U.K., comprises Russian, Switzerland, and Malta. The light blue includes the Netherlands, Italy, Denmark, and Finland. Sweden, Norway, Argentina, and Chile make up the orange cluster. The brown set, headed by Australia, includes Hong Kong, Malaysia, and Singapore. The pink group is led by the U.S.A., with India, Mexico, and New Zealand as collaborators. The salmon group comprises Germany, Romania, and South Korea. Finally, Ghana and South Africa make up the light green cluster.

Table 5 shows the characteristics of the ten countries that have published the highest number of articles and the countries they have collaborated with the most. The first in the ranking is the U.S.A., with 241 articles and 3264 citations, and it has collaborated with 96 countries, the main collaborators being the U.K., China, and Germany. In second place is the U.K. with 160 articles and 1848 citations, and it has collaborated with 76 different countries, mainly the U.S.A., Italy, and Australia. Germany occupies the third place with 95 articles and 1243 citations, and it has collaborated with 50 different countries, mainly the U.S.A., the Netherlands, and the U.K.

Table 6 shows the ten authors who have published the most on pensions. These authors represent nine different universities and countries. Most of these authors are European, although there are also two from North America.

Table 6. The top 10 most productive authors on pension research.

\begin{tabular}{|c|c|c|c|c|c|c|c|c|c|}
\hline Author & A & TC & TC/A & 1st A & Last A & $\mathrm{TC} / \mathrm{Y}$ & h-Index & Country & Affiliation \\
\hline Pestieau, P. & 12 & 169 & 14.08 & 1991 & 2012 & 5.63 & 8 & Belgium & University of Liège \\
\hline Williamson, J.B. & 11 & 151 & 13.73 & 1993 & 2020 & 5.39 & 8 & U.S.A. & Boston College \\
\hline Meijdam, L. & 10 & 182 & 18.20 & 1996 & 2017 & 7.28 & 6 & The Netherlands & Tilburg University \\
\hline Vidal-Meliá, C. & 8 & 60 & 7.50 & 2012 & 2021 & 6.67 & 6 & Spain & University of Valencia \\
\hline Casey, B.H. & 7 & 54 & 7.71 & 1998 & 2014 & 2.35 & 5 & U.K. & University of Warwick \\
\hline Holzmann, R. & 7 & 117 & 16.71 & 1989 & 2021 & 3.66 & 5 & Austria & Austrian National Bank \\
\hline Verbon, H.A.A. & 7 & 71 & 10.14 & 1996 & 2008 & 2.84 & 6 & The Netherlands & Tilburg University \\
\hline Béland, D & 6 & 81 & 13.50 & 2007 & 2019 & 5.79 & 5 & Canada & University of Saskatchewan \\
\hline Claussen, B. & 6 & 112 & 18.67 & 2007 & 2013 & 8.00 & 5 & Norway & National Institute of Public Health \\
\hline Cremer, $\mathrm{H}$. & 6 & 86 & 14.33 & 2005 & 2011 & 5.38 & 5 & France & University of Toulouse \\
\hline
\end{tabular}

A: number of articles; T.C.: total citations; TC/A: total citations by article; First A: year corresponding to first published article; Last A: year corresponding to last published article; TC/Y: average number of citations per year since the first published article; and h-index: Hirsch in this topic. Source: own elaboration.

The author with the highest number of publications is Pestieau, P. with 12 articles, followed by Williamson, J.B. with 11. However, Meijdam, L. has ten articles, the author who has received the most citations (182). The second author regarding the number of citations received is Pestieau, $P$. In terms of the results for the average number of citations per article, Claussen, B. with 18.67 is in the first position, followed by Meijdam, L. with 18.20 and Holzmann, R. with 16.71. It is curious that Verbon, H.A.A. published 6 of his 7 articles with Meijdam, L.

Different collaborative networks have been created from the co-authorships of the principal authors. These networks are shown in Figure 6. 


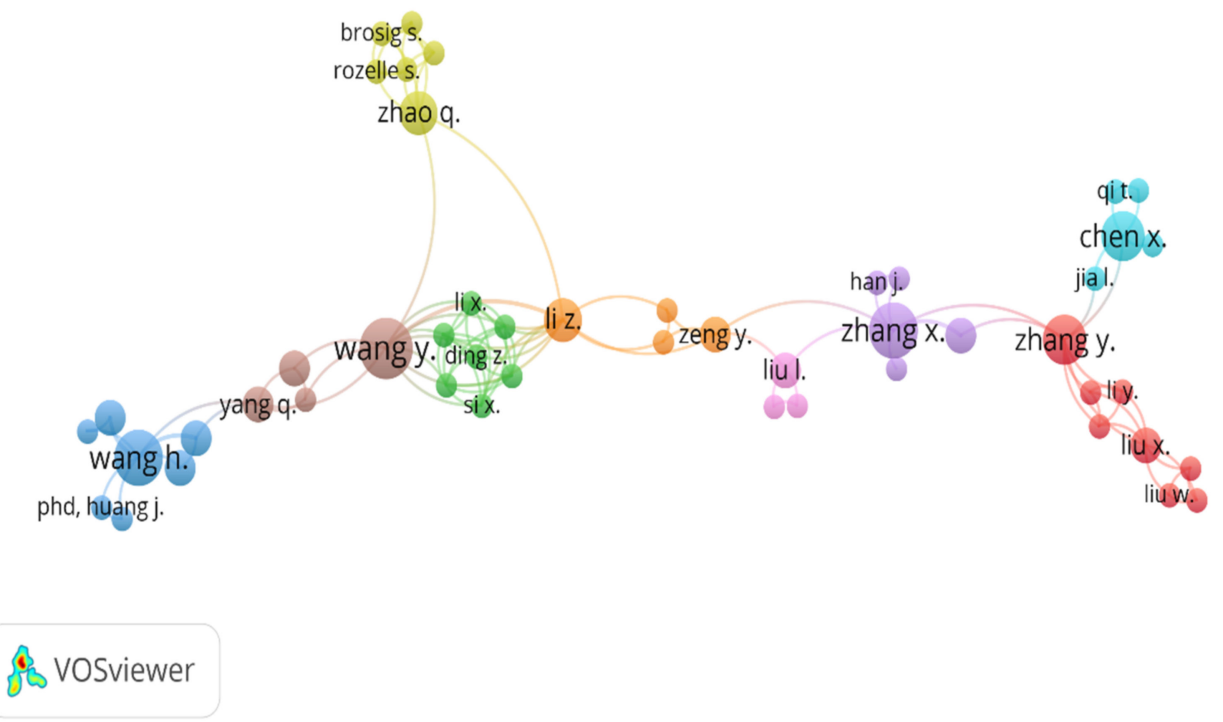

Figure 6. Network of cooperation based on co-authorship of the principal authors. Source: own elaboration.

Each of the colours corresponds to a cluster grouping its main collaborators. Nine distinct clusters have been found. The red cluster comprises eight authors: Fang I., Gong J., Li Y., Liu W., Liu X., Ning M., Pan W., and Zhang Y. The green cluster groups seven authors: Ding Z., Guo Y., Li X., Si X., Wei H., Zhang W., and Zheng S. The blue cluster is made up of five authors: Huang J., Liu Q., Shen I., Sun S., and Wang H. The yellow group is made up of six authors: Brosing S., Luo R., Rozelle S., Yue A., Zhang I., and Zhao Q. The purple cluster consists of five authors: Deng D., Han J., Meng Y., Zhang X., and Zhang Z. The light blue set also consists of five authors: Chen X., Jia L., Qi T., Sun A., and Zhong S. The orange cluster is made up of four authors: Chen Z., Li Z., Sun J., and Zeng Y. The same is true for the brown cluster, formed by: Wang Y., Xin I., Yang Q., and Zhang J. Finally, the three authors composing the pink cluster are: Liu L., Rettenmaier A.J., and Saving T.R. The brown cluster has the highest number of citations with 62 , followed by light blue with 33 , orange with 25 , blue with 20 , and purple with 19 citations. The remaining clusters have fewer than 10 citations.

Table 7 presents the characteristics of the ten institutions that have published the most articles on pensions from 1936 to 2021. These institutions are spread across seven countries, of which the U.S.A. has three institutions, and the Netherlands has two. The first two institutions, Tilburg University and the Network for Studies on Pension, Ageing and Retirement, are Dutch and have published 30 and 21 articles, respectively. The third institution is the London School of Economics and Political Science in the U.K., with 18 publications. However, these institutions are not among the most cited. The most cited institution is the U.S. National Bureau of Economic Research, which, although it has published only 14 articles, has received 761 citations. The next most cited institution is the London School of Economics and Political Science, with 388 citations.

When analysing the most cited articles from 1936 to 2021, which is very interesting, as citations show the influence of research, Table 8 shows how each of the top 10 most cited articles has received at least 84 citations. The most cited article is a paper published by Fogel et al. [78], with 226 citations since its publication in 1997. The second most cited paper, published by Mykletun et al. [79], is somewhat more recent (2006) and has received 186 citations. Furthermore, this article has the highest average number of citations per year, with 12.40 , demonstrating a high impact on the scientific literature on pensions. The third place is occupied by an article published in 2001 by Brown [80], which has received 125 citations. 
Table 7. The top 10 most productive institutions on pension research.

\begin{tabular}{|c|c|c|c|c|c|c|c|c|}
\hline Institution & Country & A & TC & TC/A & 1st A & Last A & $\mathrm{TC} / \mathrm{Y}$ & h-Index \\
\hline Tilburg University & The Netherlands & 30 & 334 & 11.13 & 1996 & 2020 & 13.36 & 9 \\
\hline $\begin{array}{c}\text { Network for Studies on Pension, } \\
\text { Ageing, and Retirement }\end{array}$ & The Netherlands & 21 & 218 & 10.38 & 2006 & 2021 & 14.53 & 7 \\
\hline $\begin{array}{l}\text { London School of Economics and } \\
\text { Political Science }\end{array}$ & U.K. & 18 & 388 & 21.56 & 1989 & 2021 & 12.13 & 12 \\
\hline $\begin{array}{l}\text { L'Organisation de Coopération et } \\
\text { de Développment Economiques }\end{array}$ & France & 17 & 225 & 13.24 & 1998 & 2016 & 9.78 & 8 \\
\hline UNSW Sydney & Australia & 16 & 134 & 8.38 & 1990 & 2021 & 4.32 & 7 \\
\hline Université de Liège & Belgium & 15 & 143 & 9.53 & 1991 & 2020 & 4.93 & 8 \\
\hline Boston College & U.S.A & 15 & 175 & 11.67 & 1993 & 2020 & 6.25 & 9 \\
\hline Harvard University & U.S.A. & 14 & 336 & 24.00 & 1978 & 2019 & 7.81 & 7 \\
\hline $\begin{array}{l}\text { National Bureau of } \\
\text { Economic Research }\end{array}$ & U.S.A. & 14 & 761 & 54.36 & 1978 & 2018 & 17.70 & 11 \\
\hline Universidad de Valencia & Spain & 12 & 78 & 6.50 & 2004 & 2021 & 4.59 & 7 \\
\hline
\end{tabular}

A: number of articles; T.C.: total citations; TC/A: total citations by article; First A: year corresponding to first published article; Last A: year corresponding to last published article; TC/Y: average number of citations per year since the first published article; and h-index: Hirsch in this topic. Source: own elaboration.

Table 8. The top 10 most cited articles.

\begin{tabular}{|c|c|c|c|c|c|}
\hline Title & Author/s & Journal & T.C. & Year & T.C./Year \\
\hline $\begin{array}{l}\text { A theory of technophysio evolution, } \\
\text { with some implications for } \\
\text { forecasting population, health care } \\
\text { costs, and pension costs }\end{array}$ & Fogel R.W., Costa D.L. & Demography & 226 & 1997 & 9.42 \\
\hline $\begin{array}{l}\text { A population-based cohort study of } \\
\text { the effect of common mental } \\
\text { disorders on disability } \\
\text { pension awards }\end{array}$ & $\begin{array}{l}\text { Mykletun A., Overland S., } \\
\text { Dahl A.A., Krokstad S., } \\
\text { Bjerkeset O., Glozier N., } \\
\text { Aarø L.E., Prince M. }\end{array}$ & $\begin{array}{l}\text { American Journal } \\
\text { of Psychiatry }\end{array}$ & 186 & 2006 & 12.40 \\
\hline $\begin{array}{l}\text { Private pensions, mortality risk, and } \\
\text { the decision to annuitise }\end{array}$ & Brown J.R. & $\begin{array}{c}\text { Journal of } \\
\text { Public Economics }\end{array}$ & 125 & 2001 & 6.25 \\
\hline $\begin{array}{l}\text { Population ageing and the rising cost } \\
\text { of public pensions }\end{array}$ & Bongaarts J. & $\begin{array}{c}\text { Population and } \\
\text { Development Review }\end{array}$ & 118 & 2004 & 6.94 \\
\hline $\begin{array}{l}\text { New evidence on pensions, social } \\
\text { security, and the timing of retirement }\end{array}$ & Samwick A.A. & $\begin{array}{l}\text { Journal of Public } \\
\text { Economics }\end{array}$ & 114 & 1998 & 4.96 \\
\hline $\begin{array}{c}\text { Ageing, pension reform, and capital } \\
\text { flows: a multi-country } \\
\text { simulation model }\end{array}$ & $\begin{array}{l}\text { Börsch-Supan A., } \\
\text { Ludwig A., Winter J. }\end{array}$ & Economics & 112 & 2006 & 7.47 \\
\hline $\begin{array}{l}\text { Social security and endogenous } \\
\text { fertility: pensions and child } \\
\text { allowances as Siamese twins }\end{array}$ & $\begin{array}{l}\text { Van Groezen B., Leers T., } \\
\text { Meijdam L. }\end{array}$ & $\begin{array}{c}\text { Journal of } \\
\text { Public Economics }\end{array}$ & 109 & 2003 & 6.06 \\
\hline $\begin{array}{l}\text { The intergenerational state education } \\
\text { and pensions }\end{array}$ & Boldrin M., Montes A. & $\begin{array}{c}\text { Review of } \\
\text { Economic Studies }\end{array}$ & 90 & 2005 & 5.63 \\
\hline $\begin{array}{c}\text { Elephants on the move. patterns of } \\
\text { public pension reform in } \\
\text { OECD countries }\end{array}$ & Hinrichs K. & European Review & 87 & 2000 & 4.14 \\
\hline $\begin{array}{c}\text { Reforming pensions: principles, } \\
\text { analytical errors, and } \\
\text { policy directions }\end{array}$ & Barr N., Diamond P. & $\begin{array}{l}\text { International Social } \\
\text { Security Review }\end{array}$ & 84 & 2009 & 7.00 \\
\hline
\end{tabular}

TC: total citations and T.C./Year: average number of citations per year since the article was published.

\subsection{Content Analysis}

\subsubsection{Research Trends}

As established by previous research in other areas of study, in order to carry out a correct analysis of the strategic diagrams, the study has to be divided into two stages $[60,73]$. For this reason, we have divided the period analysed into two periods: the first period from 1936 to 2010 and the second period from 2010 to 2021. The first period is the longest 
one, but the scientific production is smaller than the second one. The first period includes a total of 625 articles, while the second period includes 662 articles.

For each period, we will make a strategic diagram representing two dimensions on a Cartesian coordinate axis: centrality (relationship of one node of the graph to another) and density (strength of the relationship between the entities within each node). Thus, the upper right quadrant shows motor themes, i.e., closely related to each other and others. The lower right quadrant shows basic and cross-cutting themes. The upper left quadrant shows isolated themes or highly developed themes internally but not linked to the others, as is the case with motor themes. Finally, the lower left quadrant shows emerging or declining themes.

Figure 7 represents the strategic diagram of the first period from 1936 to 2010.

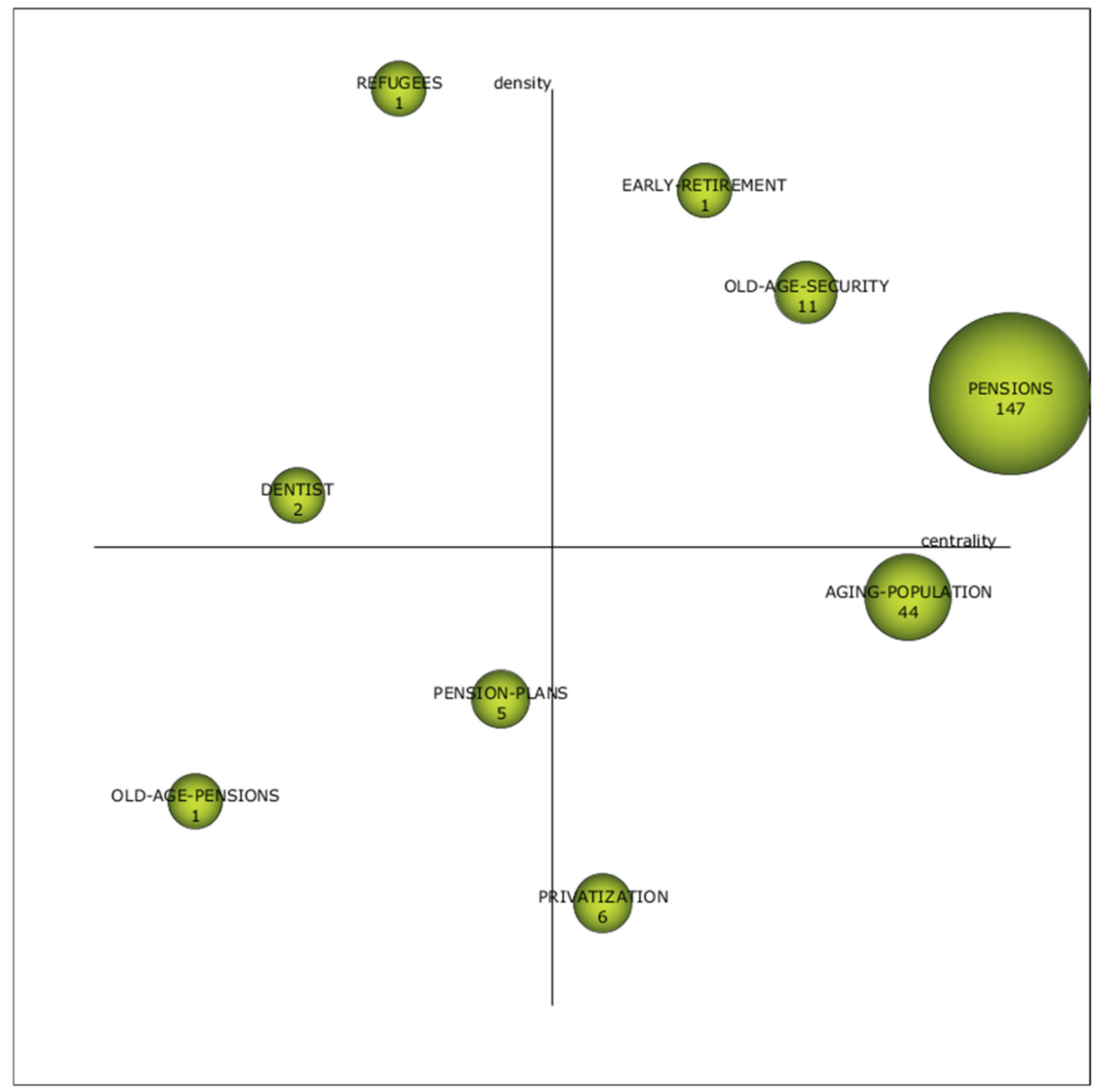

Figure 7. Strategic diagram of keywords on pension research from 1936-2010.

As can be seen, it presents three driving themes (upper right quadrant): early retirement, old age security, and pensions. These are the well-developed and essential themes of pensions research. As it is established in Table 9 and as expected, the term pensions have the highest incidence with 2214 citations. It is also customary to see a proliferation of articles on early retirement and old age security. It is due to the increasingly ageing population.

It can be seen that there are two basic themes (lower right quadrant): ageing population and privatisation. Studies on private pension systems have increased, especially in the last years. Figure 7 also presents two emerging or disappearing themes (lower left quadrant): old age pensions and pension plans. When we look at the next period, we will see whether these are emerging or disappearing themes. Finally, it can be seen and two highly developed themes: dentist and refugees. These themes are highly developed but unrelated to each other. The size of each of the circles reflects the h-index and, as can be seen, pensions and the ageing population have the highest h-index. 
Table 9. The characteristic of the strategic diagram topics on pension research from 1936 to 2010.

\begin{tabular}{cccccc}
\hline Topics & Documents & h-Index & Citations & Centrality & Density \\
\hline Pensions & 147 & 24 & 2214 & 1 & 0.67 \\
Ageing population & 44 & 13 & 528 & 0.89 & 0.44 \\
Old age security & 11 & 4 & 63 & 0.78 & 0.78 \\
Pension plans & 5 & 2 & 24 & 0.44 & 0.33 \\
Privatisation & 6 & 4 & 59 & 0.56 & 0.11 \\
Refugees & 1 & 1 & 19 & 0.33 & 1 \\
Dentist & 2 & 0 & 0 & 0.22 & 0.56 \\
Early retirement & 1 & 1 & 63 & 0.67 & 0.89 \\
Old age pensions & 1 & 1 & 1 & 0.11 & 0.22 \\
\hline
\end{tabular}

Source: own elaboration.

As can be observed in Figure 8 and Table 10, the second period from 2011 to 2021 shows four terms in each of the quadrants, except for the driving themes, which are five. The driver themes are humans, investment, social security system, pension-fund, and coronavirus infection. The appearance of a COVID-19 related issue is striking, although it is logical. As for the basic themes: pension reform, social security scheme, pension insurance, and old age pension, it can be seen that old age pension was, in the previous period, an emerging rather than a declining theme. However, the pension plan was a declining theme. In this section, the most important theme is covering studies on pension reforms. These reforms aiming at the sustainability of the system have become increasingly necessary. The emerging or disappearing themes are child allowance, personal pension, interest rate, and social pension in this period. Finally, highly developed themes, but unrelated to each other, are farmers, optimisation, labour force, and policy modelling.

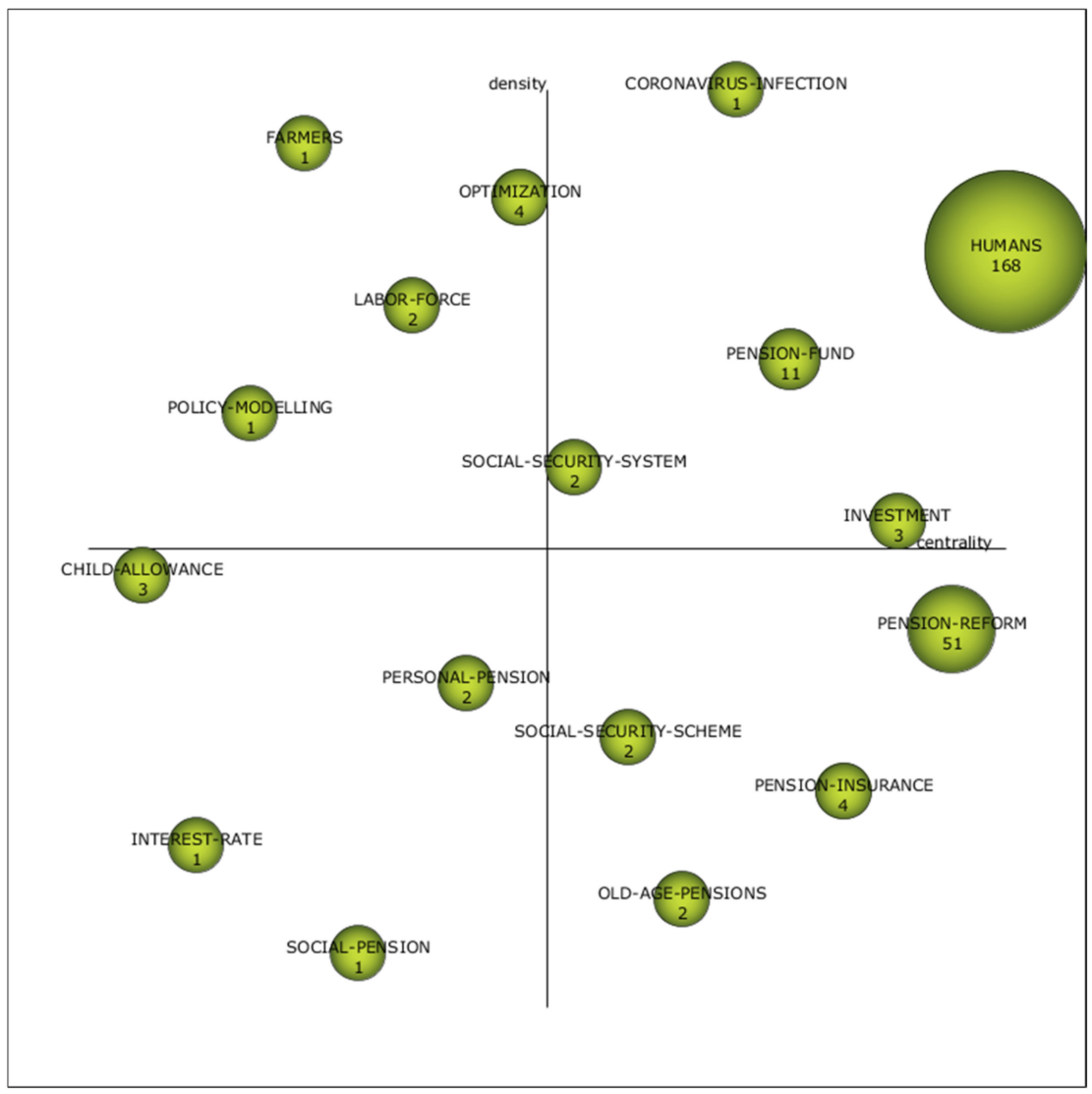

Figure 8. Strategic diagram of keywords on pension research from 2011-2021. 
Table 10. The characteristic of the strategic diagram topics on pension research from 2011 to 2021.

\begin{tabular}{cccccc}
\hline Topics & Documents & h-Index & Citations & Centrality & Density \\
\hline Humans & 168 & 16 & 1152 & 1 & 0.82 \\
Pension reform & 51 & 10 & 327 & 0.94 & 0.41 \\
Pension fund & 11 & 3 & 20 & 0.76 & 0.71 \\
Investment & 3 & 2 & 28 & 0.88 & 0.53 \\
Optimisation & 4 & 2 & 36 & 0.47 & 0.88 \\
Pension insurance & 4 & 1 & 2 & 0.82 & 0.24 \\
Labour force & 2 & 0 & 0 & 0.35 & 0.76 \\
Personal pension & 2 & 1 & 1 & 0.41 & 0.35 \\
Social security scheme & 2 & 0 & 0 & 0.59 & 0.29 \\
Child allowance & 3 & 2 & 10 & 0.06 & 0.47 \\
Social security system & 2 & 2 & 10 & 0.53 & 0.59 \\
Old age pensions & 2 & 2 & 85 & 0.65 & 0.12 \\
Farmers & 1 & 1 & 2 & 0.24 & 0.94 \\
Coronavirus infection & 1 & 0 & 0 & 0.71 & 1 \\
Policy modelling & 1 & 1 & 3 & 0.18 & 0.65 \\
Interest rate & 1 & 0 & 0 & 0.12 & 0.18 \\
Social pension & 1 & 1 & 2 & 0.29 & 0.06 \\
\hline
\end{tabular}

Source: own elaboration.

Human is the main driving theme for this second period. This theme has been covered in 168 articles and has received 1152 citations with an h-index of 16 . The second most important topic is the one dealing with the reform of pension schemes (pension reform) with a total of 51 articles, 327 citations, and an h-index of 10. In third place, although with much less importance, are the pension funds, with a total of 11 articles, 20 citations, and an h-index of 3.

Indeed, the ageing population in developed countries and the decline in the number of employed people relative to the number of retired people has led to a rethinking of the reform of traditional pension systems. The use of private pension plans and alternative life insurance to supplement state pensions is increasingly recommended, which is reflected in the scientific literature or recent years. The economic support of human beings at retirement age is a central problem in the most developed economies.

\subsubsection{Keywords}

The study of trends in pension research ends with the analysis of the 3389 keywords. It has been performed through a network visualisation map based on the co-occurrence of keywords shown in Figure 9.

Figure 9 shows how the topics of interest in pension research have evolved. Since 1995 , aspects, such as organisation, country development, and care for the elderly, were the most important topics. As time went by, the social security system and pensions gained more and more ground in the articles published, ending up in our days with an increasing concern about the much needed reform of the pension system to ensure sustainability. Furthermore, the results show that from the beginning of the period, 2010 or 2012, there was a concern about the sustainability of the social security system and the necessary pension reform. It also shows how society has become increasingly aware of the need for private coverage to complement social security pensions and how new alternative products have emerged, even to private pension plans, such as unit-linked plans, which combine insurance and investment operations in a single financial product. 


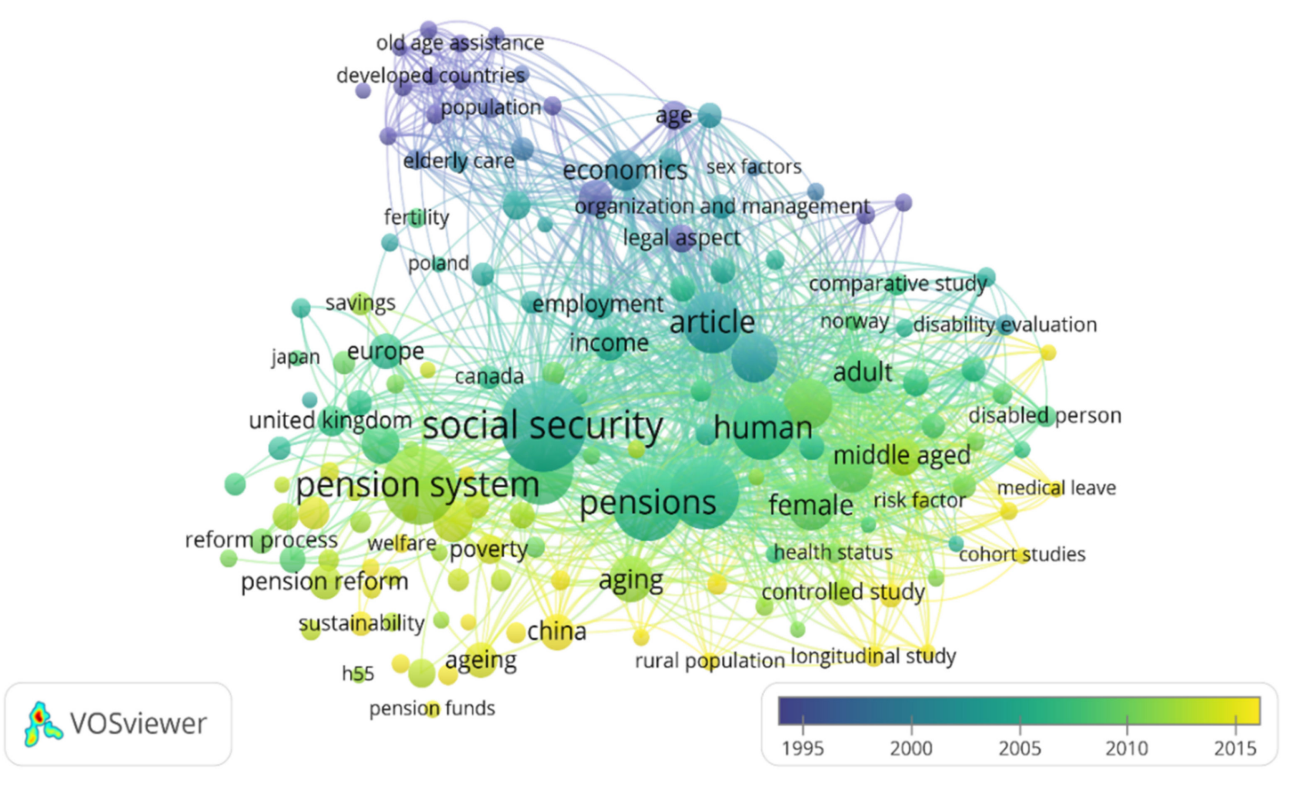

Figure 9. Evolution of the main keywords network based on co-occurrence (1936-2021). Source: own elaboration.

\subsection{Results in the Mathematics Area}

Once the bibliometric analysis of all published articles on pension research has been completed, we will carry out a specific analysis of those published in the area of Mathematics. Table 11 summarises the data obtained from the articles published in this particular area.

Table 11. Summary of data on pension research in the area of Mathematics.

\begin{tabular}{cc}
\hline Data & Pension Research \\
\hline Number of articles & 48 \\
Number of journals & 20 \\
Number of authors & 99 \\
Number of countries & 24 \\
Number of citations & 267 \\
Average citations/article & 5.56 \\
Average citations/authors & 2.70 \\
\hline
\end{tabular}

Source: own elaboration.

As can be seen in Figure 10, whose left axis represents the number of articles and the right axis the number of citations, pension research is also a topic of interest in the area of Mathematics, especially since 2008 when researchers' interest in this topic increased. The articles written in 2008, and those of 2015 and 2016, have aroused the most interest, garnering the highest number of citations.

Table 12 shows the five most productive journals in the field of pension-related research in the area of Mathematics. These journals have published 32 articles $(66.67 \%$ of the total number of articles issued). The journal that has published the most articles is Insurance: Mathematics and Economics. It has published 14 articles $(29.16 \%$ of the total number of articles published) since 2008 when it published its first article on pensions. It can also be seen that this journal has received a total of 156 citations ( $58.43 \%$ of the total number of citations received by articles on pensions in the area of Mathematics). This fact demonstrates the dominance of this journal among those mathematics journals that have published articles on pensions. However, this journal is not the most cited journal per article, ranking second with 11.14 citations per article, behind the Journal of Economic Dynamics and Control with 12.33 citations per article. As for the nationality of these journals, it should be noted that they are all published in Europe. In addition, the U.K. stands out with two such journals. It is also significant that three of the five journals are in quartile 1 
of the SCImago Journal Rank (S.J.R.), and the rest are in quartile 2, which indicates a good interest in the subject of pensions in high-impact journals.

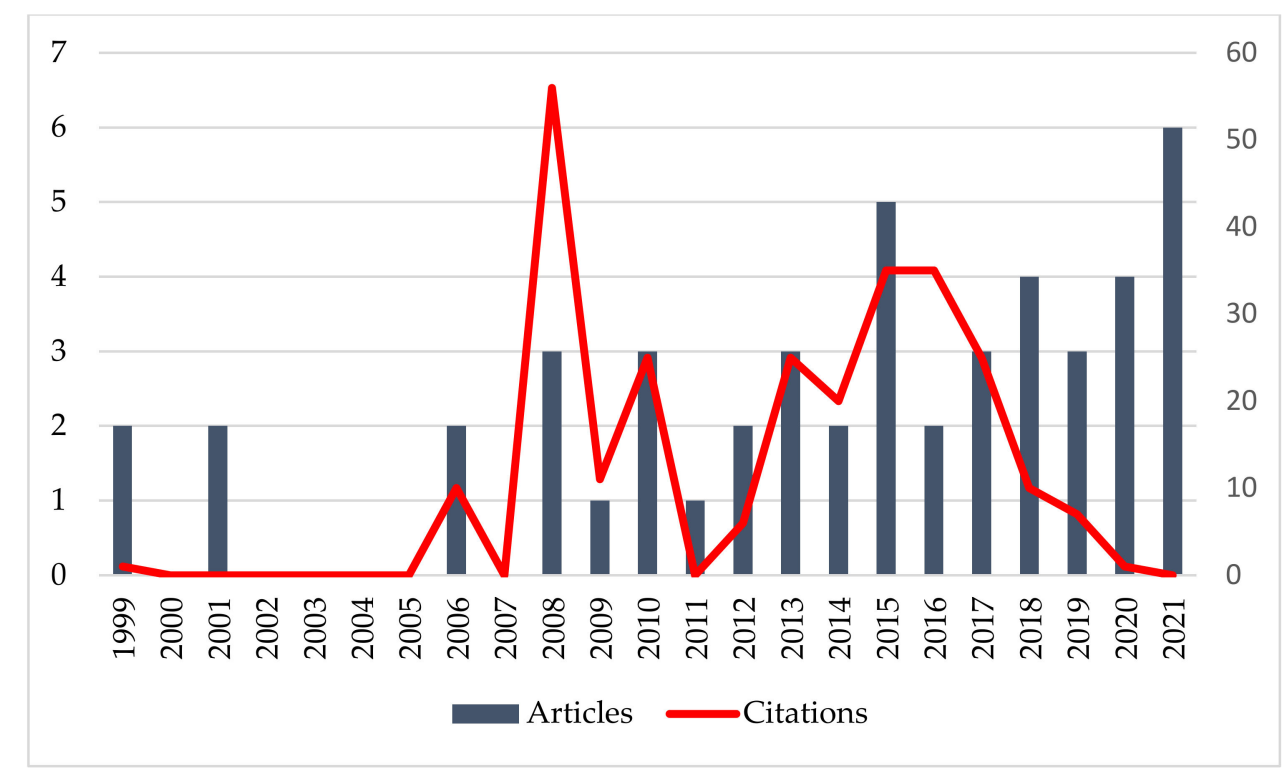

Figure 10. Evolution over time of published articles and total citations on pension research in the Mathematics area. Source: own elaboration.

Table 12. The top 5 most productive journals on pension research in the area of Mathematics.

\begin{tabular}{cccccccccc}
\hline Journal & $\mathbf{A}$ & $\mathbf{C}$ & TC & TC/A & 1st A & Last A & TC/Y & SJR(Q) & h-Index \\
\hline $\begin{array}{c}\text { Insurance: Mathematics } \\
\text { and Economics }\end{array}$ & 14 & The Netherlands & 156 & 11.14 & 2008 & 2021 & 12.00 & $1.139(\mathrm{Q} 1)$ & 7 \\
$\quad \begin{array}{c}\text { North American } \\
\text { Actuarial Journal }\end{array}$ & 8 & U.K. & 18 & 2.25 & 1999 & 2021 & 0.82 & $0.936(\mathrm{Q} 2)$ & 2 \\
$\begin{array}{c}\text { European Actuarial Journal } \\
\text { Journal of Economic Dynamics }\end{array}$ & 4 & Switzerland & 5 & 1.25 & 2019 & 2021 & 2.5 & $0.661(\mathrm{Q} 2)$ & 1 \\
$\quad \begin{array}{c}\text { and Control } \\
\text { Scandinavian Actuarial Journal }\end{array}$ & 3 & The Netherlands & 37 & 12.33 & 2006 & 2014 & 2.47 & $1.181(\mathrm{Q} 1)$ & 3 \\
\hline
\end{tabular}

A: number of articles; C: country; T.C.: total citations; TC/A: total citations by article; First A: year corresponding to first published article; Last A: year corresponding to last published article; TC/Y: average number of citations per year since the first published article; S.J.R. (Q): Scimago Journal Rank (Quartile in 2020); and h-index: Hirsch in this topic. Source: own elaboration.

Table 11 reports that 24 countries have published articles on pensions. These countries are represented in Figure 11. However, as shown in Table 13, 32 out of 48 papers have been published in 5 countries. It should be noted that an article can cover more than one country, as authors can co-author it from different institutions. The most prolific country is the U.K., with $22.91 \%$ of publications ( 11 articles), followed by the U.S.A. with $16.66 \%$ (8 articles), and the Netherlands with $10.41 \%$ (5 articles). China and Switzerland are in fourth and fifth place with four articles.

Table 13 also shows how this higher publication of articles by country does not correspond to the position in terms of citations per article received. Thus, in this case, the country that received the most citations is the Netherlands, which ranked third in terms of the number of publications. The same situation occurs with the h-index, as the Netherlands is again the country with the highest h-index with 4 and the rest with 3 , except for Switzerland, which is in last place with 1.

Figure 12 depicts networks showing cooperation among the nine major countries that have published articles on pension research in the Mathematics area. The colour of each of the spheres corresponds to a grouping of countries, while the size represents the number of articles published per country. 

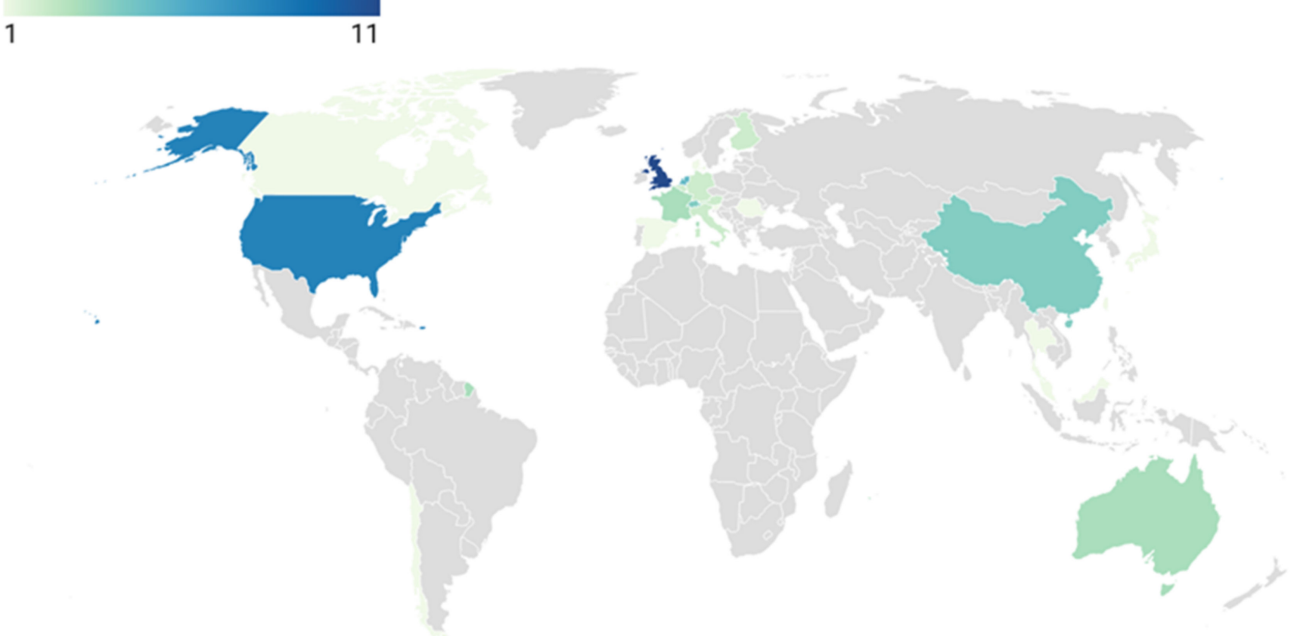

Figure 11. Worldwide publications on pension research in the Mathematics area. Source: own elaboration.

Table 13. The top 5 most productive countries on pension research in the Mathematics area.

\begin{tabular}{cccccccc}
\hline Country & A & TC & TC/A & 1st A & Last A & TC/Y & h-Index \\
\hline U.K. & 11 & 53 & 4.82 & 2010 & 2021 & 4.82 & 3 \\
U.S.A. & 8 & 26 & 3.25 & 1999 & 2021 & 1.18 & 3 \\
The Netherlands & 5 & 80 & 16.00 & 2006 & 2020 & 5.33 & 4 \\
China & 4 & 40 & 10.00 & 2012 & 2017 & 4.44 & 3 \\
Switzerland & 4 & 12 & 3.00 & 2001 & 2020 & 0.60 & 1
\end{tabular}

A: number of articles; T.C.: total citations; TC/A: total citations by article; First A: year corresponding to first published article; Last A: year corresponding to last published article; TC/Y: average number of citations per year since the first published article; and h-index: Hirsch in this topic. Source: own elaboration.

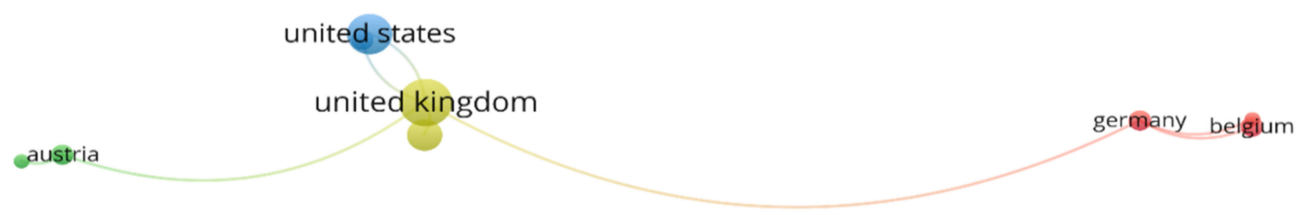

\section{\& Q Vosviewer}

Figure 12. Network of cooperation based on co-authorship between countries in the Mathematics area. Source: own elaboration.

Four different groups have been observed. The red group includes Belgium, Germany, and Luxembourg. The countries associated with the green colour are Austria and Spain. The blue cluster comprises Italy and the U.S.A. Finally, the U.K. led the yellow group, including the Netherlands.

Table 14 shows the characteristics of the countries that have collaborated most with others to publish articles on pensions in the Mathematics area. The first in the ranking is the U.K. with 11 articles, 52 citations, which has collaborated with 5 countries; the main collaborators are the U.S.A., Austria, and Germany. In second place is Germany with two articles and 25 citations; it has collaborated with 3 different countries: the U.K., Belgium, and Luxembourg. 
Table 14. Top 5 most cooperative countries and main collaborators in the Mathematics area.

\begin{tabular}{ccccc}
\hline Country & A & C & NC & Main Collaborators \\
\hline U.K. & 11 & 52 & 5 & U.S.A., Austria, Germany \\
Germany & 2 & 25 & 3 & U.K., Belgium, Luxembourg \\
U.S.A. & 8 & 26 & 2 & U.K., Italy \\
Austria & 2 & 0 & 2 & U.K., Spain \\
Belgium & 2 & 28 & 2 & Germany, Luxembourg \\
\hline
\end{tabular}

A: number of articles, C: number of citations; and NC: number of collaborations. Source: own elaboration.

Different collaborative networks have been created from the co-authorships of the main authors. These networks are shown in Figure 13. Each of the colours corresponds to a cluster grouping its main collaborators. Two distinct clusters have been found. The red cluster comprises three authors: Boado-Penas M.d.C., Godínez-Olivares, H., and Pantelous, A.A. The green cluster groups two authors: Haberman S. and Li J.

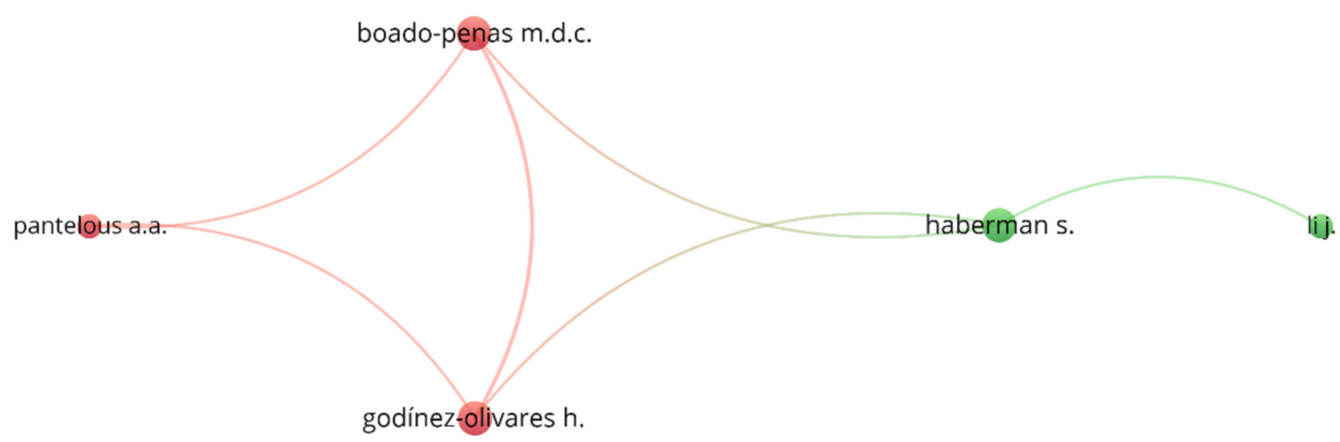

\section{VOSviewer}

Figure 13. Network of cooperation based on co-authorship of the main authors in the Mathematics area. Source: own elaboration.

Table 15 shows the five authors who have published the most on pensions. These authors represent five different universities and only two countries. The U.K. has three authors and the Netherlands has two authors. All authors have published two articles. The most cited authors are De Waegenaere, A. and Melenberg, B., with 68 citations each. In addition, both are Dutch. It is also important to note that these two authors have co-authored the two papers.

Table 15. The top 5 most productive authors on pension research in the Mathematics area.

\begin{tabular}{ccccccccccc}
\hline Author & A & TC & TC/A & 1st A & Last A & TC/Y & h-Index & Country \\
\hline De Waegenaere, A. & 2 & 68 & 34.00 & 2008 & 2010 & 5.23 & 2 & The Netherlands \\
Godínez-Olivares, H. & 2 & 35 & 17.50 & 2016 & 2016 & 7.00 & 2 & Tilburg University & U.K. \\
Haberman, S. & 2 & 30 & 15.00 & 2015 & 2016 & 5.00 & 2 & U.K. & Cass Business School \\
Kleinow, T. & 2 & 2 & 1.00 & 2019 & 2020 & 1.00 & 1 & U.K. & Heriot-Watt University \\
Melenberg, B. & 2 & 68 & 34.00 & 2008 & 2010 & 5.23 & 2 & The Netherlands & Tilburg University \\
\hline
\end{tabular}

A: number of articles; T.C.: total citations; TC/A: total citations by article; First A: year corresponding to first published article; Last A: year corresponding to last published article; TC/Y: average number of citations per year since the first published article; and h-index: Hirsch in this topic. Source: own elaboration.

Table 16 presents the characteristics of the five institutions that have published the most articles on pensions in the Mathematics area. These institutions are three from the U.K. and two from the Netherlands, and all have published three articles. The two most cited institutions are the two Dutch institutions, Tilburg University and Network for Studies on Pension, Ageing and Retirement, with 75 citations. In addition, these two institutions have the highest h-index with 3. 
Table 16. The top 5 most productive institutions on pension research in the Mathematics area.

\begin{tabular}{|c|c|c|c|c|c|c|c|c|}
\hline Institution & Country & A & TC & TC/A & 1st A & Last A & $\mathrm{TC} / \mathrm{Y}$ & h-Index \\
\hline Tilburg University & The Netherlands & 3 & 75 & 25.00 & 2006 & 2010 & 5.00 & 3 \\
\hline Heriot-Watt University & U.K. & 3 & 2 & 0.67 & 2010 & 2020 & 0.18 & 1 \\
\hline Cass Business School & U.K. & 3 & 32 & 16.00 & 2013 & 2016 & 4.00 & 2 \\
\hline University of Liverpool & U.K. & 3 & 36 & 13.00 & 2016 & 2020 & 7.20 & 2 \\
\hline $\begin{array}{c}\text { Network for Studies on Pension, } \\
\text { Ageing and Retirement }\end{array}$ & The Netherlands & 3 & 75 & 25.00 & 2006 & 2010 & 5.00 & 3 \\
\hline
\end{tabular}

A: number of articles; T.C.: total citations; TC/A: total citations by article; First A: year corresponding to first published article; Last A: year corresponding to last published article; TC/Y: average number of citations per year since the first published article; and h-index: Hirsch in this topic. Source: own elaboration.

When analysing the most cited articles in the Mathematics area, which is very interesting, as citations show the influence of research, Table 17 shows how each of the top 5 most cited articles has received at least 18 citations. The most cited article is a paper published by Hári, N. et al. [81], with 48 citations since its publication in 2008. The second most cited paper, published by Chen et al. [82], is more recent (2017) and has received 25 citations. Furthermore, this article has the highest average number of citations per year, with 6.25, demonstrating a high impact on the scientific literature on pensions in the Mathematics area. The third place is occupied by an article published in 2013 by de la Croix et al. [83], which has received 23 citations.

Table 17. The top 5 most cited articles in the Mathematics area.

\begin{tabular}{|c|c|c|c|c|c|}
\hline Title & Author/s & Journal & T.C. & Year & T.C./Year \\
\hline $\begin{array}{l}\text { Longevity risk in portfolios of } \\
\text { pension annuities }\end{array}$ & $\begin{array}{l}\text { Hári N., De Waegenaere A., } \\
\text { Melenberg B., Nijman T.E. }\end{array}$ & $\begin{array}{l}\text { Insurance: } \\
\text { Mathematics and } \\
\text { Economics }\end{array}$ & 48 & 2008 & 3.69 \\
\hline $\begin{array}{l}\text { Asset allocation under loss } \\
\text { aversion and minimum } \\
\text { performance constraint in a } \\
\text { D.C. pension plan with } \\
\text { inflation risk }\end{array}$ & Chen Z., Li Z., Zeng Y., Sun J. & $\begin{array}{l}\text { Insurance: } \\
\text { Mathematics and } \\
\text { Economics }\end{array}$ & 25 & 2017 & 6.25 \\
\hline $\begin{array}{l}\text { Ageing and pensions in } \\
\text { general equilibrium: labour } \\
\text { market imperfections matter }\end{array}$ & $\begin{array}{l}\text { de la Croix D., Pierrard O., } \\
\text { Sneessens H.R. }\end{array}$ & $\begin{array}{l}\text { Journal of } \\
\text { Economic } \\
\text { Dynamics and } \\
\text { Control }\end{array}$ & 23 & 2013 & 2.88 \\
\hline $\begin{array}{l}\text { Longevity risk in pension } \\
\text { annuities with exchange } \\
\text { options: the effect of } \\
\text { product design }\end{array}$ & $\begin{array}{c}\text { Stevens R., De Waegenaere A., } \\
\text { Melenberg B. }\end{array}$ & $\begin{array}{l}\text { Insurance: } \\
\text { Mathematics and } \\
\text { Economics }\end{array}$ & 20 & 2010 & 1.82 \\
\hline $\begin{array}{l}\text { Optimal strategies for } \\
\text { pay-as-you-go pension } \\
\text { finance: a sustainability } \\
\text { framework }\end{array}$ & $\begin{array}{c}\text { Godínez-Olivares H., } \\
\text { Boado-Penas M.D.C., } \\
\text { Haberman S. }\end{array}$ & $\begin{array}{l}\text { Insurance: } \\
\text { Mathematics and } \\
\text { Economics }\end{array}$ & 18 & 2016 & 3.60 \\
\hline
\end{tabular}

TC: total citations and T.C./Year: average number of citations per year since the article was published.

Figure 14 shows how the topics of interest in pension research in the Mathematics area have evolved. It can be seen how, at first, issues related to population, ageing, and social security were the most relevant. From 2014 onwards, topics, such as longevity, pensions, pension reform, and risk management, came to the fore. Finally, the most relevant topics are currently those related to unit-linked contracts. It is significant how this type of contract has been introduced as a means of hedging in recent years. Mortality models with covariant and survival models are also relevant topics in the area of Mathematics. 


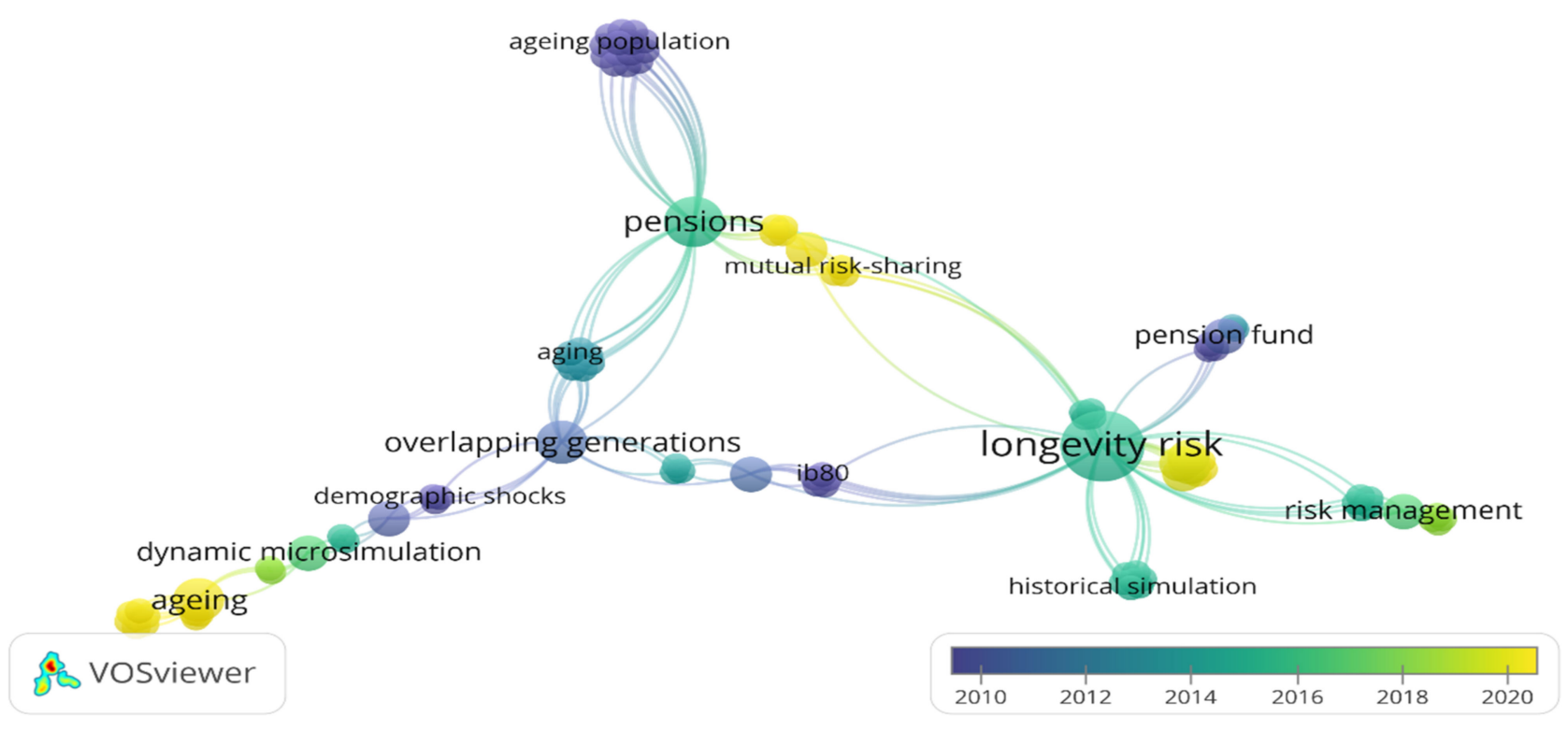

Figure 14. Evolution of main keywords network based on co-occurrence in the Mathematics area (1999-2021). Source: own elaboration.

\section{Discussion}

The research aimed to conduct a bibliometric analysis of published research on pensions through a structured literature review. The study was carried out on a total of 1287 articles published from 1936 to 2021 and found in the Scopus database. The study analysed the most relevant indicators that characterise an article, such as authors, journals, countries, institutions, subject areas, keywords, and citations.

The results obtained show that since the first article on pensions was published in 1936, the number of articles has not stopped growing. This growth has been very significant in the last ten years, where more than half of the papers have been published. The increasing interest in pensions has been due to concerns about the difficulty of sustaining pensions in the future. This expansion in the number of articles published has led to an increase in the number of authors, countries, and journals interested in this topic in recent years.

The results also show that the main subject area in which these articles have been published is Economics, Econometrics, and Finance with $32.77 \%$ of the production, followed by Social Sciences with $28.45 \%$, and Business, Management, and Accounting with $12.12 \%$. The journal that has published the most articles is the International Social Security Review, with 122 articles. This journal is also the one that has received the most citations, with 1092. In addition, it has also been found that the most productive journals are in the upper quartiles of Scopus.

Analysing the number of countries that have contributed to the pension literature, we can see that the number is 112. However, half of the articles published have been from only one country, with the U.S.A. being the most productive country. Another important conclusion to note is that the 10 journals that have published the most articles belong to Western countries, 8 European countries and 2 to North America, which shows the greater interest in the more developed countries in the future of pensions. Strong collaborative networks between these countries in pension research have also been demonstrated.

It can be seen as the author with the highest number of publications is Pestieau, P. with 12 articles, followed by Williamson, J.B. with 11 . However, neither of these two authors is the one who receives the most citations, as this first place is occupied by Meijdam, L., with 182 citations. The findings also show the existence of important collaborative networks among authors specialising in this field.

Another important issue analysed was the contribution by institutions, with 2 Dutch institutions publishing the most articles, with 30 and 21, respectively. However, it is a U.S. institution, with 14 articles, that has received the most citations, with 761 . On the other 
hand, the most cited article has been published by Fogel R. W. et al. [78], with 226 citations since its publication in 1997.

Finally, an analysis of the latest trends in pension research shows that the most current topics are humans and pension funds, with 168 and 51 articles, respectively.

A specific analysis of the 48 articles published in the area of Mathematics has also shown a growing interest in recent years, with a significant increase in production in 2021. We can find articles published by 99 authors representing 24 different countries within this thematic area. The most important journal in this area is Insurance: Mathematics and Economics, with 14 articles and 156 citations. It is important to note that the prominent journals in this area are all European. Finally, the results show that the five authors who published the most on pensions represent five different universities and only two countries (the U.K. and the Netherlands).

\section{Conclusions}

This research has made it possible to demonstrate how a topical issue, such as pensions, can be analysed from a wide variety of perspectives through the use of appropriate bibliometric tools. It has been very relevant to note how the scientific community's interest in pensions has not stopped growing since the publication of its first article in 1936 and how it has performed so exponentially in recent years. It is also significant to see the evolution of the topics analysed. It has gone from a concern about life expectancy and population ageing to the current primary concern regarding the sustainability of pensions in the not too distant future.

This article contributes to the theoretical development of pension research by enabling researchers to identify the main research topics and future lines of research on which they can focus their research: humans, pension funds, pension insurance, and pension reforms.

This research's great added value is the simultaneous use of three important bibliometric tools: Datawrapper, ScimMat, and VOSviewer. This fact is unusual for other bibliometric analyses, which usually focus on the use of a single tool.

The knowledge provided by this study on trends in pension research is the major contribution of this research. The search for new financial systems to sustain pensions is the primary trend at present. Reforms are necessary, as is the supplementary pension insurance and the latest generation of financial instruments, such as unit-linked.

Identifying the current trends and which topics are no longer of interest to researchers will make finding new niches for pension research easier.

This research provides an overall picture of the evolution of researchers' concerns about pensions since 1936. Thus, it has been possible to verify the evolution of the main driving themes throughout the period analysed. This evolution has been correlated with the concerns of society at each point in time, which is why it has gone from a problem for early retirement or life expectancy at the end of the 20th century to the current concern for the sustainability of the system.

This research is not without limitations, which could become future lines of research. As this article has been carried out only with the Scopus database, future research could be extended to other databases, such as Google Scholar. On the other hand, a study could be carried out using only the information provided by the Web of Science database due to the higher reputation of this database [84]. The scope could also be widened by analysing other documents in addition to journal articles, especially books, in which valuable works on the study of pensions can also be found. Even a single keyword could be used in the analysis, such as pensions, to see the trends in the broader field of research.

Author Contributions: Conceptualisation, M.d.C.V.M., J.M.S.-J. and P.A.M.-C.; methodology, M.d.C.V.M., J.M.S.-J. and F.-u.A.; software, M.d.C.V.M. and P.A.M.-C.; validation, M.d.C.V.M., J.M.S.-J., F.-u.A. and P.A.M.-C.; formal analysis, M.d.C.V.M., J.M.S.-J. and F.-u.A.; investigation, M.d.C.V.M. and J.M.S.-J.; writing —original draft preparation, M.d.C.V.M. and J.M.S.-J.; writing—review and editing, M.d.C.V.M. and J.M.S.-J.; supervision, M.d.C.V.M. All authors have read and agreed to the published version of the manuscript. 
Funding: This research received no external funding.

Institutional Review Board Statement: Not applicable.

Informed Consent Statement: Not applicable.

Data Availability Statement: Not applicable.

Conflicts of Interest: The authors declare no conflict of interest.

\section{References}

1. Alonso-García, J.; Rosado-Cebrian, B. Financial crisis and pension reform in Spain: The effect of labour market dynamics. J. Econ. Policy Reform 2021, 24, 201-218. [CrossRef]

2. Hinrichs, K. Recent pension reforms in Europe: More challenges, new directions. An overview. Soc. Policy Adm. 2021, 55, 409-422. [CrossRef]

3. Pérez-Salamero González, J.M.; Regúlez-Castillo, M.; Vidal-Meliá, C. Differences in Life Expectancy Between Self-Employed Workers and Paid Employees when Retirement Pensioners: Evidence from Spanish Social Security Records. Eur. J. Popul. 2021, 37, 697-725. [CrossRef] [PubMed]

4. Valls Martínez, M.d.C.; Cruz Rambaud, S.; Abad Segura, E. Savings operations over random periods. Cogent Bus. Manag. 2018, 5, 1515572. [CrossRef]

5. Symeonidis, G.; Tinios, P.; Xenos, P. Enhancing Pension Adequacy While Reducing the Fiscal Budget and Creating Essential Capital for Domestic Investments and Growth: Analysing the Risks and Outcomes in the Case of Greece. Risks 2020, 9, 8. [CrossRef]

6. Weaver, R.K. The politics of pensions: Lessons from abroad. In Framing the Social Security Debate; National Academy of Social Insurance: Washington, DC, USA, 1998; pp. 183-229.

7. Wolf, I.; Lopez del Rio, L.C.y. The Expectation for Pension Insurance in Funded Schemes: Theoretical Model and Global Implementation. Acad. J. Interdiscip. Stud. 2021, 10, 161. [CrossRef]

8. Ebbinghaus, B. The varieties of pension governance. In Pension Privatization in Europe; Oxford University Press: Oxford, UK, 2011.

9. Möhring, K. Employment histories and pension incomes in Europe: A multilevel analysis of the role of institutional factors. Eur. Soc. 2015, 17, 3-26. [CrossRef]

10. Hammond, R.; Baxter, S.; Bramley, R.; Kakkad, A.; Mehta, S.; Sadler, M. Considerations on State Pension Age in the United Kingdom. Br. Actuar. J. 2016, 21, 165-203. [CrossRef]

11. Wang, X.; Williamson, J.B.; Cansoy, M. Developing countries and systemic pension reforms: Reflections on some emerging problems. Int. Soc. Secur. Rev. 2016, 69, 85-106. [CrossRef]

12. Febrero, E.; Cadarso, M.Á. Pay-As-You-Go versus funded systems. Some critical considerations. Rev. Polit. Econ. 2006, 18, 335-357. [CrossRef]

13. Fernández López, S.; Vivel Búa, M.; Otero González, L.; Rodeiro Pazos, D. El ahorro para la jubilación en la UE: Un análisis de sus determinantes. Rev. Econ. Mund. 2012, 31, 111-135.

14. Hira, T.K.; Rock, W.L.; Loibl, C. Determinants of retirement planning behaviour and differences by age. Int. J. Consum. Stud. 2009, 33, 293-301. [CrossRef]

15. Pan, G.; Li, S.; Geng, Z.; Zhan, K. Do Social Pension Schemes Promote the Mental Health of Rural Middle-Aged and Old Residents? Evidence From China. Front. Public Health 2021, 9, 710128. [CrossRef]

16. Lee, S.-L.; Park, M.-H.; Montalto, C.P. The effect of family life cycle and financial management practices on household saving patterns. Int. J. Hum. Ecol. 2000, 1, 79-93.

17. Fontes, A. Differences in the likelihood of ownership of retirement saving assets by the foreign and native-born. J. Fam. Econ. Issues 2011, 32, 612-624. [CrossRef]

18. Harrysson, L.; Montesino, N.; Werner, E. Preparations for retirement in Sweden: Migrant perspectives. Crit. Soc. Policy 2016, 36, 531-550. [CrossRef]

19. Díaz Casero, J.C.; Fernández Portillo, A.; Sánchez Escobedo, M.C.; Hernández Mogollón, R. Estructura intelectual del fracaso empresarial. Faedpyme Int. Rev. 2014, 3, 43-55. [CrossRef]

20. Shi, Y.; Li, X. An overview of bankruptcy prediction models for corporate firms: A systematic literature review. Intang. Cap. 2019, 15, 114-127. [CrossRef]

21. Li, H.; Yu, J.-L.; Yu, L.-A.; Sun, J. The clustering-based case-based reasoning for imbalanced business failure prediction: A hybrid approach through integrating unsupervised process with supervised process. Int. J. Syst. Sci. 2014, 45, 1225-1241. [CrossRef]

22. Payán-Sánchez, B.; Belmonte-Ureña, L.J.; Plaza-úbeda, J.A.; Vazquez-Brust, D.; Yakovleva, N.; Pérez-Valls, M. Open innovation for sustainability or not: Literature reviews of global research trends. Sustainability 2021, 13, 1136. [CrossRef]

23. Merigó, J.M.; Yang, J.-B. A bibliometric analysis of operations research and management science. Omega 2017, 73, 37-48. [CrossRef]

24. Snyder, H. Literature review as a research methodology: An overview and guidelines. J. Bus. Res. 2019, 104, 333-339. [CrossRef]

25. Pak, T.-Y. What are the effects of expanding social pension on health? Evidence from the Basic Pension in South Korea. J. Econ. Ageing 2021, 18, 100287. [CrossRef] 
26. Ronne-Engström, E.; Alexanderson, K.; Friberg, E. Sickness absence, disability pension and economic situation after a spontaneous subarachnoid haemorrhage among people of working age: A Swedish longitudinal nationwide cohort study. BMJ Open 2021, 11, e040941. [CrossRef] [PubMed]

27. Samsuddin, S. Are There Adequate Benefits and Contributions for SOCSO's Invalidity Pension Scheme (I.P.S.)? ASM Sci. J. 2021, 16, 1-7. [CrossRef]

28. Valls Martínez, M.d.C.; Martín Cervantes, P.A.; Soriano Román, R. Public Management Resources of the NHS. In Global Encyclopedia of Public Administration, Public Policy, and Governance; Springer: Cham, Switzerland, 2021; pp. 1-7. [CrossRef]

29. Okulicz-Kozaryn, A.; Morawski, L. A similar effect of volunteering and pensions on subjective wellbeing of elderly. Econ. Sociol. 2021, 14, 11-39. [CrossRef]

30. Yasuoka, M. How should a government finance pension benefits? Aust. Econ. Pap. 2021, 60, 138-152. [CrossRef]

31. Owadally, I.; Ram, R.; Regis, L. An analysis of the Dutch-style pension plans proposed by UK policy-makers. J. Soc. Policy 2021, 1-21. [CrossRef]

32. Fong, J.H.; Piggott, J.; Sherris, M. Longevity selection and liabilities in public sector pension funds. J. Risk Insur. 2015, 82, 33-64. [CrossRef]

33. Komp, K.; Johansson, S. Population ageing in a lifecourse perspective: Developing a conceptual framework. Ageing Soc. 2016, 36, 1937-1960. [CrossRef]

34. Martin, L.G. Demography and aging. In Handbook of Aging and the Social Sciences; Binstock, R.H., George, L.K., Eds.; Academy Press: London, UK, 2010; pp. 33-45. ISBN 978-0-12-380880-6.

35. Okulicz-Kozaryn, A.; Morawski, L. Effect of Volunteering and Pensions on Subjective Wellbeing of Elderly-Are there CrossCountry Differences? Appl. Res. Qual. Life 2021, 16, 1943-1959. [CrossRef]

36. Balsameda, M.; Melguizo, A.; Taguas, D. Las reformas necesarias en el sistema de pensiones contributivas en España. Moneda Crédito 2006, 222, 313-340.

37. Ni, S.; Podgursky, M. How Teachers Respond to Pension System Incentives: New Estimates and Policy Applications. J. Labor Econ. 2016, 34, 1075-1104. [CrossRef]

38. Danzer, A.M.; Dolton, P.; Bondibene, C.R. Who wins? Evaluating the impact of U.K. public sector pension scheme reforms. Natl. Inst. Econ. Rev. 2016, 237, R38-R46. [CrossRef]

39. Disney, R. Pension reform in the United Kingdom: An economic perspective. Natl. Inst. Econ. Rev. 2016, 237, R6-R12. [CrossRef]

40. Clark, R.L.; Hanson, E.; Mitchell, O.S. Lessons for public pensions from Utah's move to pension choice. J. Pension Econ. Financ. 2016, 15, 285-310. [CrossRef]

41. Farrell, J.; Shoag, D. Asset management in public DB and non-DB Pension Plans. J. Pension Econ. Financ. 2016, 15, 379-406. [CrossRef]

42. Lewis, G.B.; Stoycheva, R.L. Does Pension Plan Structure Affect Turnover Patterns? J. Public Adm. Res. Theory 2016, 26, 787-799. [CrossRef]

43. Platanakis, E.; Sutcliffe, C. Pension Scheme Redesign and Wealth Redistribution Between the Members and Sponsor: The U.S.S. Rule Change in October 2011. Insur. Math. Econ. 2016, 69, 14-28. [CrossRef]

44. Boldrin, M.; Dolado, J.J.; Jimeno, J.F.; Peracchi, F. The future of pension systems in Europe. Econ. Policy 1999, $29,286-323$.

45. Yang, Z. Population aging and public pension: The case of Beijing analysed by an OLG model. Singapore Econ. Rev. 2016, 61, 1-14. [CrossRef]

46. Robertson-Rose, L. Understanding Default Behaviour in Workplace Pensions: Automatic Enrolment in the UK. J. Soc. Policy 2021, 50, 21-39. [CrossRef]

47. Prattley, J.; Chandola, T. The Influence of Household Pension Wealth, Partner's Health and Spousal Employment Status on Heterogeneous Early Retirement Transitions among Women in England. Work. Employ. Soc. 2021, 35, 57-77. [CrossRef]

48. Cesaratto, S. The Economics of Pensions: A non-conventional approach. Rev. Polit. Econ. 2002, 14, 149-177. [CrossRef]

49. Cesaratto, S. Transition to fully funded pension schemes: A non-orthodox criticism. Cambridge J. Econ. 2006, 30, 33-48. [CrossRef]

50. Van Praag, B.M.S.; Hop, J.P. Demography and provisions for retirement: The pension composition, a behavioral approach. J. Demogr. Econ. 2021, 87, 1-31. [CrossRef]

51. Harris, M.N.; Loundes, J.; Webster, E. Determinants of Household Saving in Australia. Econ. Rec. 2002, 78, 207-233. [CrossRef]

52. Huberman, G.; Iyengar, S.S.; Jiang, W. Defined contribution pension plans: Determinants of participation and contributions rates. J. Financ. Serv. Res. 2007, 31, 1-32. [CrossRef]

53. Miti, J.J.; Perkiö, M.; Metteri, A.; Atkins, S. Pension coverage extension as social innovation in Zambia: Informal economy workers' perceptions and needs. Int. Soc. Secur. Rev. 2021, 74, 29-53. [CrossRef]

54. Wang, H.; Huang, J. How Can China's Recent Pension Reform Reduce Pension Inequality? J. Aging Soc. Policy 2021, 1-15. [CrossRef] [PubMed]

55. Rahman, M.; Khan, T.I.; Sabbih, M.A. An Estimation of the Implementation Costs and Financing Options for Introducing a Universal Pension Scheme in Bangladesh. South Asia Econ. J. 2021, 22, 110-131. [CrossRef]

56. Wang, Q.; Timonen, V. Retirement pathways and pension inequality in China: A grounded theory study. Int. J. Sociol. Soc. Policy 2021, 41, 96-111. [CrossRef]

57. Forman, J.B. Removing the legal impediments to offering lifetime annuities in pension plans. Conn. Insur. Law J. 2016, $23,31-141$.

58. Winter, P.; Planchet, F. Modern tontines as a pension solution: A practical overview. Eur. Actuar. J. 2021, 1-30. [CrossRef] 
59. Merigo, J.M.; Blanco-Mesa, F.; Gil-Lafuente, A.M.; Yager, R.R. Thirty years of the International Journal of Intelligent Systems: A bibliometric review. Int. J. Intell. Syst. 2017, 32, 526-554. [CrossRef]

60. Zambrano Farias, F.; Valls Martínez, M.d.C.; Martín-Cervantes, P.A. Explanatory Factors of Business Failure: Literature Review and Global Trends. Sustainability 2021, 13, 10154. [CrossRef]

61. Li, Z.C.; Huang, H.J.; Yang, H. Fifty years of the bottleneck model: A bibliometric review and future research directions. Transp. Res. Part B Methodol. 2020, 139, 311-342. [CrossRef]

62. Small, H. Visualizing science by citation mapping. J. Am. Soc. Inf. Sci. 1999, 50, 799-813. [CrossRef]

63. Cobo, M.J.; López-Herrera, A.G.; Herrera-Viedma, E.; Herrera, F. Science mapping software tools: Review, analysis, and cooperative study among tools. J. Am. Soc. Inf. Sci. Technol. 2011, 62, 1382-1402. [CrossRef]

64. Castillo-Vergara, M.; Alvarez-Marin, A.; Placencio-Hidalgo, D. A bibliometric analysis of creativity in the field of business economics. J. Bus. Res. 2018, 85, 1-9. [CrossRef]

65. Jeong, D.; Koo, Y. Analysis of Trend and Convergence for Science and Technology using the VOSviewer. Int. J. Contents 2016, 12, 54-58. [CrossRef]

66. Cobo, M.J.; López Herrera, A.G.; Herrera Viedma, E.; Herrera, F. SciMAT: A new Science Mapping Analysis Software Tool. J. Am. Soc. Inf. Sci. Technol. 2012, 63, 1609-1630. [CrossRef]

67. Da Silva Pereira, R.; de Resende, L.M.M.; Betim, L.M.; Bonatto, F.; von Agner, T. Systematic Bibliometric Analysis of Horizontal Network of Enterprises. IFAC-PapersOnLine 2015, 48, 1821-1826. [CrossRef]

68. Sweileh, W.M. Research trends on human trafficking: A bibliometric analysis using Scopus database. Global. Health 2018, 14, 1-12. [CrossRef] [PubMed]

69. Dupleix, M.D.; Rébori, A. Strategy and turnaround in declining firms: A literature review of the past 15 years. Estud. Gerenciales 2017, 33, 141-152. [CrossRef]

70. Moed, H.; De Bruin, R.; Van Leeuwen, T.H. New bibliometric tools for the assessment of national research performance: Database description, overview of indicators and first applications. Scientometrics 1995, 33, 381-422. [CrossRef]

71. León-gómez, A.; Ruiz-palomo, D.; Fernández-gámez, M.A.; García-revilla, M.R. Sustainable Tourism Development and Economic Growth: Bibliometric Review and Analysis. Sustainability 2021, 13, 2270. [CrossRef]

72. López Núñez, J.A.; López-Belmonte, J.; Moreno-Guerrero, A.-J.; Ramos Navas-Parejo, M.; Hinojo-Lucena, F.-J. Education and diet in the scientific literature: A study of the productive, structural, and dynamic development in web of science. Sustainability 2020, 12, 4838. [CrossRef]

73. Terán-Yépez, E.; Marín-Carrillo, G.M.; del Pilar Casado-Belmonte, M.; de las Mercedes Capobianco-Uriarte, M. Sustainable entrepreneurship: Review of its evolution and new trends. J. Clean. Prod. 2020, 252, 1-21. [CrossRef]

74. Shah, S.H.H.; Lei, S.; Ali, M.; Doronin, D.; Hussain, S.T. Prosumption: Bibliometric analysis using HistCite and VOSviewer. Kybernetes 2019, 49, 1020-1045. [CrossRef]

75. Raghav, R.S.; Pothula, S.; Vengattaraman, T.; Ponnurangam, D. A survey of data visualisation tools for analysing large volume of data in big data platform. In Proceedings of the 2016 International Conference on Communication and Electronics Systems (ICCES), Coimbatore, India, 21-22 October 2016; pp. 1-6.

76. Caldarelli, G.; Ellul, J. Trusted Academic Transcripts on the Blockchain: A Systematic Literature Review. Appl. Sci. 2021, 11, 1842. [CrossRef]

77. Kraus, S.; Li, H.; Kang, Q.; Westhead, P.; Tiberius, V. The sharing economy: A bibliometric analysis of the state-of-the-art. Int. J. Entrep. Behav. Res. 2020, 26, 1769-1786. [CrossRef]

78. Fogel, R.W.; Costa, D.L. A theory of technophysio evolution, with some implications for forecasting population, health care costs, and pension costs. Demography 1997, 34, 49-66. [CrossRef] [PubMed]

79. Mykletun, A.; Overland, S.; Dahl, A.A.; Krokstad, S.; Bjerkeset, O.; Glozier, N.; Aarø, L.E.; Prince, M. A population-based cohort study of the effect of common mental disorders on disability pension awards. Am. J. Psychiatry 2006, 163, 1412-1418. [CrossRef] [PubMed]

80. Brown, J.R. Private pensions, mortality risk, and the decision to annuitise. J. Public Econ. 2001, 82, 29-62. [CrossRef]

81. Hari, N.; De Waegenaere, A.; Melenberg, B.; Nijman, T.E. Longevity risk in portfolios of pension annuities. Insur. Math. Econ. 2008, 42, 505-519. [CrossRef]

82. Chen, Z.; Li, Z.; Zeng, Y.; Sun, J. Asset allocation under loss aversion and minimum performance constraint in a DC pension plan with inflation risk. Insur. Math. Econ. 2017, 75, 137-150. [CrossRef]

83. De la Croix, D.; Pierrard, O.; Sneessens, H.R. Aging and pensions in general equilibrium: Labor market imperfections matter. J. Econ. Dyn. Control 2013, 37, 104-124. [CrossRef]

84. Zhao, X. A scientometric review of global BIM research: Analysis and visualisation. Autom. Constr. 2017, 80, 37-47. [CrossRef] 